\title{
A HISTORIOGRAFIA DOS PRIMEIROS TEMPOS DO BRASIL MODERNO. TENDÊNCIAS E DESAFIOS DAS DUAS ÚLTIMAS DÉCADAS*
}

\author{
The Historiography of Early Modern Brazil. \\ Tendencies and challenges of the last two decades
}

Stuart B. Schwartz ${ }^{* *}$

\section{RESUMO}

Esse ensaio examina a importante produção histórica sobre o Brasil colonial, nos últimos vinte anos e observa que as diversas comemorações - a viagem de Colombo, o descobrimento do Brasil, a abolição da escravidão, bem como a transferência da Corte - deram origem a uma grande leva de publicações e guias de pesquisas. Ao longo deste período, a historiografia enfatizou a História Cultural em vez da História Social, e foi fortemente influenciada pela França, Itália, Portugal e Estados Unidos. Esse trabalho não abrange toda a riqueza da recente produção historiográfica e, portanto, se concentra, unicamente, sobre quatro temas principais: o primeiro é o crescente interesse pela História dos indígenas brasileiros, inspirado nos estudos antropológicos modernos; o segundo é a cultura afro-brasileira e a escravidão que continuam sendo um grande foco de pesquisas; o terceiro é a História Cultural da colônia, com uma ênfase sobre mentalidades, cultura material e dissidência; e, finalmente, um retorno ao governo e à administração que se aproveitou da revitalização da História Moderna dos primeiros tempos em Portugal pós-Salazar.

Palavras-chave: Brasil colônia; historiografia; história cultural.

\begin{abstract}
This essay reviews the considerable historical production on colonial Brazil in the last twenty years. It notes that the various commemorations

\footnotetext{
"Artigo traduzido por Germaine Mandelsaft.

"* Professor da Cathedra George Burton Adams, Universidade de Yale, EUA.
} 
of the Columbus voyage, the discovery of Brazil, the abolition of slavery, and the transference of the court have resulted in a "boom" of publications and research guides. Over this period the historiographical trend has been from social to cultural history with influences from France, Italy, Portugal, and the United States particularly strong. The essay can not cover the full richness of recent historiographical production and thus concentrates on four principal themes. It notes the growing interest in the history of the Brazilian Indians, greatly influenced by modern anthropological studies; Afro-Brazilian culture and slavery which continues to be a major field of concentration; the cultural history of the colony with emphasis on mentalities, material culture, and dissidence; and finally a new return to the history of governance and administration that has profited greatly from the resurgence of early modern history in post-Salazar Portugal.

Key-words: Colonial Brazil; historiography; cultural History.

Embora a maioria dos acadêmicos seja unânime em pensar que, nos primeiros tempos do Brasil Moderno, o país tinha uma relação classicamente colonial com a sua metrópole - Portugal - a maioria dos povos que viviam no Brasil durante os primeiros trezentos e vinte e dois anos acreditavam que residiam no "Estado do Brasil" ou no "Estado do Maranhão". Esses dois Estados eram as duas unidades administrativas da América portuguesa e somente pouco a pouco os seus habitantes perceberam que seu status era de dependência ou colonial.

Esse ponto, recentemente ressaltado por Laura de Mello e Souza, entre outros historiadores, enfatiza, novamente, as percepções, as crenças, as impressões e a compreensão das pessoas que viveram no passado, mais que as etiquetas analíticas e as interpretações dos tempos modernos.

De certa maneira, isso representa uma redireção na escrita e conceitualização da história do Brasil dos primeiros tempos ${ }^{1}$. Certamente, nem todos os historiadores abandonaram a categoria analítica do "Brasil colonial”, mas essa nova ênfase nas ideias e padrões de pensamentos contemporâneos da época em questão é significativa de várias transformações

1 Ver a entrevista com Laura de Mello e Souza, em “Entrevistas”, Pós-história, v. 6, 1998. Ela publicou Cotidiano e vida privada na América Portuguesa, v. I da História da vida privada no Brasil. In: NOVAIS, Fernando A. (Ed.). 4 v. São Paulo: Companhía das Letras, 1997-98, e escolheu o título porque o termo "Brasil colonial" foi uma invenção do século XIX. 
nos métodos históricos e abordagens características do passado recente da escrita da história do Brasil, anterior à independência.

As últimas duas décadas foram marcadas por uma intensa produtividade e por uma crescente sofisticação nos estudos do Brasil dos primeiros três séculos. Nos Estados Unidos, os estudos sobre o Brasil Moderno dos primeiros tempos são menos importantes em relação aos estudos sobre a América Hispânica, no que diz respeito à popularidade e às publicações. Isso pode ser explicado por razões linguísticas e geográficas, como também pelo fato de existirem menos norte-americanos de origem brasileira que norte-americanos de origem hispânica. No entanto, podese afirmar que, de um modo geral, o conhecimento da era moderna dos primeiros tempos no Brasil passou a desempenhar um papel importante a partir dos anos de 1980.

Essa tendência foi influenciada, do ponto de vista teórico, por um processo de transformação nas ciências sociais, pela guinada cultural na História, por novas tecnologias da informação - digitalização e internet - e por uma série de comemorações que geraram um suporte institucional de publicações, colóquios e pesquisas ${ }^{2}$.

Esse texto não pode abranger toda a amplitude dessas mudanças nem mesmo incluir todos os trabalhos mais importantes que foram realizados desde meados dos anos 1980. Portanto, tentarei identificar uma série de temas e questões que orientam grande parte desta produção histórica; em seguida, tentarei listar os textos mais importantes que levam o campo histórico para novas direções, e, finalmente, discutirei as mudanças de foco nos estudos históricos, destacando alguns dos trabalhos que foram seminais no estudo do Brasil colonial.

2 Outros debates historiográficos sobre as recentes mudanças nos estudos sobre o Brasil colonial incluem ARRUDA, José Jobson; TEGARRINHA, José Manuel (Eds.). Historiografia Luso-Brasileira contemporânea. Bauru: EDUSC, 1999; ARRUDA, José Jobson; FONSECA, Luís Adão da. Brasil-Portugal: História, agenda para o milênio. Bauru: EDUSC, 2001; RUSSELL-WOOD, A.J.R. "Archives and the Recent Historiography on Colonial Brazil”. In: Latin American Research Review, v. 36, n. 1, 2001, p. 75-103; "United States Scholarly Contributions to the Historiography of Colonial Brazil". In: Hispanic American Historical Review, v. 65, n. 4, 1985, p. 683-723; FURTADO, Júnia. Novas tendências da historiografia sobre Minas Gerais no período colonial; MARTINS, Roberto; MARTINS, Amilcar Vianna (Eds.). Historiografia mineira nos últimos 20 anos. Belo Horizonte: ICAM, est. 2007. Tratei algumas questões historiográficas, anteriormente, em SCHWARTZ, Stuart B. "Somebodies and Nobodies in the Body Politic: Mentalities and Social Structures in Colonial Brazil”. In: Latin American Research Review, v. 31, n. 1, 1996, p. 113-134; "The Colonial Past: Conceptualizing Post-Dependentista Brazil". In: ADEIMAN, Jeremy (Ed.). Colonial Legacies. New York: Routledge, 1999, p. 175-93; e em "Brazil: Ironies of the Colonial Past". In: HAHR, v. 80, n.4, 2000, p. 681-694. 
Durante o período de 1985 até os dias atuais, o Brasil comemorou tanto o aniversário dos 500 anos de 1492, como os 500 anos da viagem de Cabral de 1500, que fazia parte do ciclo de viagens iniciado por Vasco da Gama em 1498, extensamente comemorado pela Comissão Nacional para a Comemoração dos Descobrimentos do Portugal. Estas comemorações, assim como o centenário da abolição da escravidão no Brasil (1988), provocaram debates virulentos e críticas e, muitas vezes, atuaram como válvulas de escape para diversas frustrações. Elas foram denunciadas por grupos que se sentiram traídos pela história subsequente, mas foram objeto de celebração nacional. Portanto, no Brasil, o público em geral, e diferentes grupos e movimentos - aqueles que procuram o progresso dos direitos das populações indígenas, os movimentos políticos afro-brasileiros, e os que procuram mudanças políticas e econômicas em um país que apresenta uma das piores distribuições de renda do mundo - se voltaram para a história do Brasil dos primeiros tempos, com um interesse renovado ${ }^{3}$. Mas, independentemente dos motivos políticos de tal questionamento, as comemorações e anticomemorações enfocaram o rumo da história do Brasil, e no Brasil, em Portugal e em outros lugares, houve um interesse renovado pelos primeiros séculos da história brasileira ${ }^{4}$. Os resultados institucionais mais importantes decorrentes deste impulso comemorativo sobre os estudos do Brasil dos primeiros tempos se expressaram, sem dúvida, em monografias, conferências, revistas acadêmicas, edições de textos clássicos e documentos patrocinados por vários programas governamentais e instituições não governamentais no Brasil; da mesma forma, nos extensos e importantes programas acadêmicos apoiados pela Comissão Portuguesa sobre os Descobrimentos, que foi, infelizmente, suspensa em 2001, porque não tinha nenhuma visão de longo prazo ${ }^{5}$.

3 Foram publicados ensaios gerais sobre a era colonial, como CALDEIRA, Jorge. A nação mercantilista. Rio de Janeiro: Editora 34, 1999, e manuais, como VAINFAS, Ronaldo Vainfas (Ed.). Dicionário do Brasil Colonial. Rio de Janeiro: Editora Objetiva, 2000, e muita cobertura das mídias.

4 Esses anos viram a grande popularidade de livros sobre a história dos primeiros tempos do Brasil, como a série escrita por Eduardo Bueno, uma telenovela intitulada $A$ muralha, sobre a colonização da cidade de São Paulo nos primeiros tempos, a publicação de dois dicionários úteis de história colonial brasileira, e várias sínteses sobre a era colonial. Ver: NIZZA DA SILVA, Maria Beatriz (Ed.). Dicionário da história da colonização portuguesa no Brasil. Lisboa: Verbo, 1994; VAINFAS, Ronaldo (Ed.). Dicionário do Brasil Colonial. Rio de Janeiro: Objetiva, 2000; WEHLING, Arno; WEHLING, Maria José C. de. Formação do Brasil Colonial. Rio de Janeiro: Nova Fronteira, 1994.

5 Ver: HESPANHA, António Manuel. Há 500 anos: Balanço de três anos de comemorações dos descobrimentos portugueses 1996-98. Lisboa, 1999, para um resumo das numerosas atividades da Comissão 
$\mathrm{O}$ vasto projeto que consiste em microfilmar e disponibilizar as fontes documentais sobre o Brasil colonial nos arquivos estrangeiros veio da disponibilidade dos recursos e do suporte institucional proporcionados pelo quinto centenário. Esse Projecto Resgate iniciou seu programa colocando, em CD-ROMs, todas as matérias relacionadas ao Brasil no Arquivo Histórico Ultramarino, o principal arquivo colonial do Portugal. Apesar dos problemas de distribuição e das dificuldades técnicas, esse programa ajudou bastante os pesquisadores para consultar uma das principais fontes da história brasileira dos primeiros tempos ${ }^{6}$. Numerosas publicações acadêmicas on line se desenvolveram, tais como eJournal of

durante esses anos. Ela publicou uma revista digna de atenção, Oceanos, em formato extragrande, que tinha excelentes artigos e uma iconografia esplêndida, inclusive vários números dedicados, inteiramente ou em parte, ao Brasil dos primeiros tempos. Ver por exemplo: "Vieira, 1697". In: Oceanos, v. 30-31, 1997; “Azulejos. Portugal e Brasil”. In: Oceanos, v. 36-37, 1998-99; "A formação territorial do Brasil”. In: Oceanos, v. 40, 1999; "A Construção do Brasil”. In: Oceanos, v. 41, 2000; "Viver no Brasil colônia". In: Oceanos, v. 42, 2000. Dois dos mais importantes acervos documentais publicados no período foram a correspondência entre Luís e Gaspar de Souza e as cartas do Conde da Torre publicadas pela Comissão Nacional para as Comemorações dos Descobrimentos Portugueses (posteriormente abreviada pela sigla CNCDP) e o importante Códice Costa Matoso, uma coleção de matérias ligadas a Minas Gerais. Ver: SALVADO, João Paulo; MIRANDA, Susana Münch (Eds.). Livro 1 do Governo do Brasil (1607-1633). Lisboa: Comissão Nacional para as Comemorações dos Descobrimentos Portugueses, 2001; Livro 2 do Governo do Brasil (1615-1634). Lisboa: CNCDP, 2001; Cartas para Álvaro de Sousa e Gaspar de Sousa. Lisboa: CNCDP, 2001; cartas do 1 Code da Torre, 4 v. Lisboa: CNCDP, 2001; FIGUEIREDO, Luciano Raposo de Almeida; CAMPOS, Maria Verônica Campos (Eds.). Coidice Costa Matoso: coleção das notiìcias dos primeiros descobrimentos das minas na Ameìrica que fez o doutor Caetano da Costa Matoso sendo ouvidor-geral das Vilas do Ouro Preto. 2 v. Belo Horizonte: Sistema Estadual de Planejamento, Fundação João Pinheiro, Centro de Estudos Históricos e Culturais, 1999. Outra coleção importante foi a série de traduções e fac-símiles de publicações do período do domínio holandês no Nordeste do Brasil (1630-54), com o patrocínio da Petrobrás, publicada pela Editora Index. Ver, por exemplo: WAGENER, Zacharias. $O$ "Thierbuch" e "Autobiografia". 2 v. Rio de Janeiro: Editora Index, 1997; TEENSMA, B.N. (Ed.). Dezessete cartas de Vincent Joachim Soler, 1636-43. Rio de Janeiro: Editora Index, 1999; PAPAVERO, Nelson; TEIXEIRA, Dante Martins (Eds.). Cudburt Pudsey. Journal of a Residence in Brazil. Petrópolis: Editora Index, 2000.

6 Mais de 250.000 documentos foram microfilmados no Arquivo Histórico Ultramarino. O Projecto Resgate de Documentação Histórica Barão Rio Branco foi descentralizado, de certa forma, e assim a distribuição dos CD-ROMs e a publicação dos catálogos e guias para os documentos de cada capitania foram administradas pelas atuais secretarias de Estado ou universidades brasileiras para cada região. Isso causou grandes problemas na distribuição dos discos e na finalização dos guias. Para exemplos de guias, ver: BOSCHI, Caio (Ed.). Inventário dos manuscritos avulsos relativos a Minas Gerais existentes no Arquivo Histórico Ultramarino (Lisboa). 3 v. Belo Horizonte: Fundação João Pinheiro, Centro de Estudos Históricos e Culturais, 1998; Catálogo de verbetes dos documentos manuscritos avulsos da capitania de Mato Grosso (1720-1827). Campo Grande, MS: Casa da Memória, Arnaldo Estevão de Figueiredo e Universidade Federal de Mato Grosso, 1999; JUCÁ, Gisafran Nazareno Mota (Ed.). Catálogo dos documentos manuscritos avulsos da capitania de Ceará (1618-1832). Brasília e Fortaleza: Ministério da Cultura e Universidade Federal de Ceará, 1999. 
Portuguese History e Almanack Braziliense, ao lado de primorosas revistas de história, como Tempo e Topoi (Rio de Janeiro), Revista Brasileira de História, Varia Historia (Minas Gerais), Afro-Asia (Salvador) Revista de História (São Paulo), Anais de História de Além-mar e Penélope (Lisboa). Todos esses periódicos publicam, sistematicamente, trabalhos importantes sobre o Brasil colonial. Existem agora estudiosos que trabalham sobre o Brasil dos primeiros tempos em praticamente todos os Estados do país e existem, também, influentes centros de história colonial, baseados em universidades como a Universidade de São Paulo, a Universidade Federal do Rio de Janeiro, a Universidade Federal Fluminense (Niterói), a Universidade Federal de Minas Gerais e a Universidade de Campinas.

\section{Da História Social à História Cultural}

Uma visão marxista ou estruturalista do Brasil anterior a 1808, com uma economia baseada na exportação de escravos, vinculada ao desenvolvimento de um capitalismo mercantil de uma Europa em plena expansão, é o paradigma que domina o pensamento histórico sobre o Brasil desde a década de 1930. Autores tais como Oliveira Viana, Gilberto Freyre, Roberto Simonsen, Caio Prado Jr. e Florestan Fernandes, nem todos eles marxistas, contribuíram de diversas formas para uma visão do Brasil dos primeiros tempos, que enfatiza as relações sociais patriarcais e semifeudais, o "imperativo econômico inelutável" da escravidão e os aspectos negativos da sua orientação exportadora e da sua dependência dos mercados mundiais. Essa visão, estreitamente ligada à teoria da dependência, tem vantagens indiscutíveis. Ela forneceu uma interpretação coerente do passado brasileiro, que eliminou as noções extravagantes das cronologias políticas, e colocou os problemas duradouros de dependência econômica, de classe e raça no coração da História brasileira. Esta interpretação, enfatizando a situação do Brasil colonial, orientou grande parte do trabalho realizado a partir da década de 1960 até a década de 1980, e continua influenciando o conhecimento nos dias atuais, mas a sua ênfase nas estruturas econômicas e na natureza comercial da colônia parece representar um determinado tipo de teleologia que fez 
da Europa ou da metrópole a protagonista da história colonial. Ela também excluiu ou subestimou grandes segmentos da população e quase não tocou em questões como sexualidade, gênero, sistemas de crença, ritual, identidade e formas de representação, todos eles temas e tópicos que eram importantes para a nova História Cultural. A reação a esta interpretação estruturalista veio em duas fases. Na década de 1970, houve uma série de estudos enfatizando os contextos sociais e as atividades de diferentes instituições, bem como a composição e as ações de vários grupos sociais, tais como comerciantes, lavradores de cana, plantadores de açúcar, Cristãos Novos ou homens livres de cor. Como parte da História Social daquele tempo, esses estudos foram, muitas vezes, caracterizados por um enfoque metodológico sobre comportamentos coletivos e uniformidades, que atraiu a atenção dos estudiosos brasileiros sobre o uso de métodos quantitativos, apesar do fato de que eles, frequentemente, procuravam (com relativo sucesso) voltarse às teorias, geralmente marxistas, para evitar as piores deficiências do positivismo norte-americano. De várias maneiras, o movimento da História Social no Brasil não foi uma rejeição do paradigma estruturalista, mas um desenvolvimento dentro dele, que transferiu o foco para a colônia e a agência para grupos e indivíduos locais. Na década de 1980, a guinada para a História Social e a História Econômica gerou uma série de importantes estudos sobre instituições e grupos sociais, que tentaram analisar a forma como os atores coletivos históricos responderam às limitações estruturais do regime colonial. Isso fica evidente nos estudos da escravidão, em que uma série de análises fundamentais do sistema escravista, elaboradas na década de 1960, foram seguidas, nos anos 1970 e 1980, por um aumento da produção de estudos sobre a resistência, a rebeldia, a família, a demografia e a alforria. Essa produção destaca a ação dos escravos, sua resistência e volição, o que foi apelidado de "agência" de escravos, frente às limitações estruturais e às assimetrias do poder. Esses estudos mudaram o foco para as condições locais e os esforços individuais ou coletivos no Brasil e fora do sistema colonial, como um todo 7 . Do ponto de vista metodológico, muitos trabalhos, durante este período, continuaram utilizando análises quantitativas e alguns dos melhores estudos foram produzidos nos campos econômicos

7 GORENDER, Jacob. A escravidão reabilitada. São Paulo: Ática, 1990, sugeriu que o foco na agência de escravos exonerava a escravidão de seus pecados e apresentava uma imagem cor-de-rosa da instituição, mas sua crítica não teve uma grande influência nos estudos posteriores. 
e demográficos, que estavam abertos a essa abordagem. Globalmente, as realizações historiográficas da História Social eram impressionantes; elas possibilitavam mostrar a complexidade e a contingência da História, onde a interação dinâmica das forças sociais e políticas, frequentemente, desafiava a interpretação predominantemente estruturalista.

O movimento da História Social na História do Brasil colonial foi ultrapassado, na década de 1990, por uma segunda leva de estudos que demonstraram descontentamento com predominantes interpretações que pareciam enfatizar conformidades, o poder do estado e pressões sobre ações humanas. Influenciados por abordagens mais recentes na Europa e por estudos de gênero, pela História das mentalités, pela etno-história e pela crítica literária e cultural, estudiosos no Brasil - como no resto do mundo - começaram a se voltar para temas como infância, corpo, sexualidades, linguagem, representações e identidades. Nesta mudança de foco, os brasileiros tiveram seus próprios precursores endógenos, especialmente no que diz respeito ao trabalho do antropólogo social polifacetado Gilberto Freyre, cuja fascinação por uma variedade de assuntos, da família até a sexualidade, passando pela etiqueta à mesa, foi uma espécie de História Cultural avant la lettre, e cujo legado para a vida cultural brasileira é, ainda, tema de muitos debates $^{8}$. No entanto, a História Cultural no Brasil não tomou o lugar da História Social da década precedente, mas a desenvolveu, e ofereceu uma variedade de oportunidades para combinações e hibridizações metodológicas de vários tipos.

Dois grandes projetos em colaboração anunciaram e ratificaram a guinada cultural da historiografia brasileira desde meados da década de 1980. A História da vida privada (4 v., 1997) sob a direção geral de Fernando A. Novais, foi baseada numa coleção francesa com mesmo tema. Nela, o volume dedicado à época colonial incluía muitos historiadores brasileiros importantes que tinham migrado da História Social para a História Cultural. Os ensaios desse volume enfatizavam os aspectos da vida familiar, sexualidade, cultura material e religiosidade. Posteriormente, os dois

8 GIUCCI, Guillermo; LARRETA, Enrique Rodríguez; FONSECA, Edson Nery da (Eds.). Gilberto Freyre. Casa-grande \& senzala, edição crítica. Madrid: Allca xx, 2002. Ver também: BURKE, Maria Lúcia Pallares. Gilberto Freyre. Um vitoriano nos trópicos. São Paulo: UNESP, 2005; ARAÚJO, Ricardo Benzaquen de. Guerra e paz. Casa-grande \& senzala e a obra de Gilberto Freyre nos anos 30. São Paulo: Editora 34, 2004. 
volumes da coleção Festa, publicada em 2002, marcaram também outro aspecto da guinada cultural, enfatizando festivais, procissões, exposições públicas e outras atividades lúdicas ${ }^{9}$. Juntos, esses volumes serviram como pontos de referência para a guinada cultural na historiografia colonial brasileira. Mas, gostaria de ressaltar aqui que a História Cultural no estudo do Brasil dos primeiros tempos não foi, verdadeiramente, objeto de uma "guinada cultural": ela se manteve estreitamente ligada à História Social, e ambas permaneceram na sombra, ou pelo menos sob a influência das visões estruturalistas do passado brasileiro. Assim, mesmo quando se trata de derrubar aspectos dessas interpretações, os termos e agendas dos debates continuam sendo aqueles que foram desenvolvidos em meados do século $\mathrm{XX}$, ou seja, o lugar da colônia em um sistema global mercantil, o papel do Estado e sua relação com o poder local, a assimetria das relações sociais, bem como a forma e a função da escravidão enquanto sistema econômico, e um fator determinante das atitudes e dos relacionamentos humanos. Entretanto, a preocupação com a esfera privada e a vida íntima se desenvolveu ao lado da preocupação mais tradicional com a esfera pública, e ambas tenderam a se juntar analiticamente. Finalmente, é importante ressaltar aqui que a historiografia colonial brasileira, bem como a da América hispânica, foi fortemente influenciada pela História Social anglo-americana, pela microhistória italiana e pela historiografia social e cultural francesa. Porém, ela foi também profundamente afetada, nas últimas duas décadas, pelo renascimento da História do início da era moderna no Portugal pós-Salazar, um desenvolvimento singular, que enriqueceu e aprofundou a análise do Portugal e de seu império, incluindo o Brasil. O objetivo restrito deste ensaio é examinar as tendências historiográficas deste período, examinando quatro temas importantes que foram cruciais para uma grande parte da historiografia das últimas duas décadas.

9 NOVAIS, Fernando A. História da vida privada. 4 v. São Paulo: Companhia das Letras, 1997; JANCSÓ, István; KANTOR, Iris. Festa. Cultura e sociabilidade na América portuguesa. São Paulo: Hucitec, 2001. 


\section{O retorno dos nativos}

Ambos quintos centenários, o aniversário da primeira viagem de Colombo (1992) e o desembarque de Cabral no Brasil (2000) estimularam um novo interesse pelas Histórias dos povos nativos do Brasil. Em um período em que há, ao mesmo tempo, uma marginalização, cada vez maior, dos povos indígenas e tribais, e uma crescente autoidentificação dos povos rurais como índios - em razão de vantagens legais na aquisição de terras que lhes dão também um status étnico e econômico mais elevado -, a historiografia ligada aos povos indígenas do Brasil na era colonial entrou num período de maior sofisticação. Um dos momentos decisivos foi, sem dúvida, a publicação da História dos Índios do Brasil (1992) pela antropóloga Manuela Carneiro da Cunha. Essa obra se focaliza na Amazônia, mas contém também artigos sobre outras regiões e representa um esforço deliberado para associar historiadores e antropólogos num projeto comum. Entretanto, o livro não possui um método ou uma abordagem que unifica as duas disciplinas. Esse volume foi seguido, em 1999, por Cambridge History of Native American Peoples. V. III South America, que inclui uma visão geral da história indígena brasileira por pesquisadores brasileiros e estrangeiros, como Robin Wright, John Monteiro e Manuela Carneiro da Cunha. Ambas as obras se afastavam de uma abordagem estruturalista - mas não a rejeitavam -, ou pelo menos de uma integração desses métodos que podem ser chamados de etno-históricos ${ }^{10}$.

O livro de John Hemming, Red Gold: the destruction of the Brazilian Indians (1978) iniciou, muito detalhadamente, essa história triste e o volume subsequente relatou os acontecimentos dos meados do século dezoito até o século vinte ${ }^{11}$. O texto de John Monteiro, Negros da terra (1998), foi uma contribuição muito importante para o conhecimento das

10 CUNHA, Manuela Carneiro da (Ed.). História dos Índios do Brasil. São Paulo: Companhia das Letras, 1992; SALOMON, Frank; SCHWARTZ, Stuart B. (Eds.). Cambridge History of Native Peoples of the Americas. V. 3 South America, parts 1 and 2. Cambridge: Cambridge University Press, 1999-2000.

11 HEMMING, John. Amazon Frontier. The Defeat of the Brazilian Indians. London: MacMillan, 1987. 
sociedades indígenas e o seu contato com os portugueses no sul do Brasil ${ }^{12}$. Monteiro destacou a integração dos povos indígenas na economia colonial, reunindo as matérias históricas e etnológicas. Ele ressaltou a importância do trabalho dos índios como uma etapa do desenvolvimento do Sul do Brasil, exatamente como estudos prévios para o Nordeste ${ }^{13}$. Pesquisas sobre contatos anteriores foram ampliadas por novas edições de textos clássicos, como aqueles escritos por Fernão Cardim e Simão de Vasconcellos. As mais notáveis são o estudo de Whitehead e Harbsmeier e a edição do relato clássico de Hans Staden, cujo valor etnográfico se manifesta no texto e nas ilustrações ${ }^{14}$. Também houve uma renovação do interesse por La France Antarctique, esse posto avançado na baía de Guanabara e, em geral, pelas tentativas da França de explorar (nos dois sentidos) o litoral brasileiro ${ }^{15}$. Leyla Perrone Moisés apresenta uma instigante análise literária e histórica da viagem de Paulmier de Gonneville, em 1503-05. O trabalho de Frank Lestringant foi particularmente importante, porque estimulou um interesse renovado pela France Antarctique e pela questão da percepção e da representação dos Tupis e, principalmente, pela prática do canibalismo ${ }^{16}$. Andrea Daher estudou o fracasso da colônia do Maranhão; ela analisou o encontro dos missionários Capuchinhos com os habitantes indígenas e o seu reflexo sobre as recentes abordagens culturais e religiosas nos estudos da História do início da Europa Moderna ${ }^{17}$.

12 MONTEIRO, John. Negros da terra: índios e bandeirantes nas origens de São Paulo. São Paulo: Companhia das Letras, 1994. Ver também seu ensaio que fornece uma visão geral "The Crises and Transformations of Invaded Societies: Coastal Brazil in the Sixteenth Century". In: Cambridge History of Native Peoples of the Americas, v. 3, pt.1, p. XXXX.

13 Por exemplo, SCHWARTZ, Stuart B. "Indian Labor and New World Plantations". In: American Historical Review, v. 83, n.1, 1978, p. 43-79; Sugar Plantations in the Formation of Brazilian Society. Cambridge: Cambridge University Press, 1985, p. 51-72.

14 Ver, também, WHITEHEAD, Neil L. "Hans Staden and the Cultural Politics of Cannibalism". In: $H A H R$, v. 80 , n. 4, 2000, p. 721-51.

15 WHATLEY, Janet. Jean de Léry, History of the Voyage to the Land of Brazil. Traduzido e editado. Berkeley: University of California Press, 1990. Ver, também, CONLEY, Conley. "Thevet Revisits Guanabara". In: $H A H R$, v. 80, n. 4, 2000, p. 753-781.

16 PERRONE-MOISÉS, Leyla. Vinte luas. Viagem de Paulmier de Gonneville ao Brasil: $1503-$ 1505. São Paulo: Companhia das Letras, 1992; LESTRINGANT, Frank. Le Huguenot et le sauvage. $\mathrm{T}^{\mathrm{rd}} \mathrm{ed.}$ Genebra: Droz, 2004. A edição original é Paris: Amateur des Livres, 1990. Ver também LESTRINGANT, Frank. Cannibals: the discovery and representation of the Cannibal from Columbus to Jules Verne. Traduzido por Rosemary Morris. Cambridge: Polity Press, 1997.

17 DAHER, Andrea. Les singularités de la France Équinoxiale. Paris: Honoré Champion, 2002; publicado em Português sob o titulo O Brasil francês. Rio de Janeiro: Civilização Brasileira, 2007. Ver também o estudo mais geral de PIANZOLA, Maurice. Des Français à la conquête du Brésil 17ème siècle. Les perroquets jaunes. Paris: L'Harmattan, 1991. 
Em certa medida, o interesse renovado pelos estudos da História Indígena no Brasil foi impulsionado por importantes estudos etnográficos modernos realizados por antropólogos conscientes das fontes históricas - e das crônicas desses encontros. As suas pesquisas deram uma nova orientação e impulsão para os historiadores voltarem, com um novo enfoque, para os textos clássicos. Nessa perspectiva, as pesquisas de Eduardo Viveiros de Castro sobre a violência e o canibalismo e as de Hélène Clastres sobre o messianismo Tupi-Guarani foram cruciais ${ }^{18}$. Enquanto os contatos dos Tupinambás, dos Tupiniquins e de outros grupos Tupis com os Europeus no século XVI tinham dominado a historiografia da geração anterior de pesquisadores, estudos sérios e inovadores surgiram, nos últimos vinte anos, sobre pessoas cujo idioma não era o Tupi e sobre os períodos mais recentes de conquista e contato. Foram publicados estudos interessantes sobre os Taiririu tapuya, índios no Brasil holandês ${ }^{19}$. A guerra dos bárbaros (2000), de Pedro Puntoni, analisa a abertura do sertão de Pernambuco, Paraíba e Rio Grande do Norte. O relato detalhado das expedições de conquista do sertão e a narração da destruição dos povos que lá viviam é uma crônica da segunda parte do século XVII. Marcos Galindo examinou a abertura da "fronteira de gado solto" no rio São Francisco, no sertão de Rodelas, e os esforços dos Capuchinhos e dos Jesuítas para realizar um mandato missionário ${ }^{20}$. Duas pesquisas essenciais realizadas por Langfur e Espínola examinaram a penetração do Rio Doce em Minas Gerais e a resistência dos Grens ou Botocudos durante os séculos XVIII e XIX ${ }^{21}$. Esses estudos demonstram que a penetração do sertão era descontínua, o território colonial não era contíguo e grandes porções do território mantiveram-se fora do controle colonial

18 CLASTRES, Hélène. The Land-without-Evil: Tupiì-Guaraniì prophetism. Traduzido do francês por Jacqueline Grenez Brovender. Urbana: University of Illinois Press, 1995; CASTRO, Eduardo Viveiros de. From the enemy's point of view: humanity and divinity in an Amazonian society. Traduzido por Catherine V. Howard. Chicago: University of Chicago Press, 1992.

19 Ver, por exemplo, BOOGART, Ernst van den. "Infernal allies: The Dutch West India Company and the Tarairiu". In: Johan Maurits van Nassau-Siegen, 1604-1679. E. van den Boogart (Ed.) The Hague: Johan Maurits van Nassau Stichting, 1979, p. 518-38; RAMINELLI, Ronald. "Habitus caníbal. Os índios de Albert Eckhout”. In: HERKENHOFF, Paulo (Ed.). O Brasil e os holandeses. Rio de Janeiro: Sextante, 1999, p. 104-121. 1798. N.p., 2004

20 GALINDO, Marcos. O governo das almas. A expansão colonial no país dos tapuia, 1651 -

21 LANGFUR, Hal. The Forbidden Lands: Colonial Identity, Frontier Violence, and the Persistence of Brazil's Eastern Indians, 1750-1830. Stanford: Stanford University Press, no prelo. ESPINDOLA, Haruf Salmen. Sertão do Rio Doce. Bauru: EDUSC, 2005. 
até os meados do século XIX. A extensão desse controle e o processo de contato é o enfoque de novos estudos sobre bandeirismo por A. Metcalf, M. Karasch, H. Langfur e A.J.R. Russell-Wood, em um número especial de The Americas publicado em 2005 ${ }^{22}$. Langfur e Schwartz investigaram as relações, pouco estudadas, entre os povos indígenas e os afro-brasileiros, um tema que foi também abordado por Santos Gomes. A. Metcalf sugeriu que as ideias milenaristas acabaram por ser compartilhadas também pelos escravos africanos ${ }^{23}$. Mary Karasch publicou um grande número de trabalhos abrangentes sobre a abertura do extremo oeste brasileiro, dando muita atenção às relações dinâmicas e à criação de identidades entre os brancos, índios e africanos na fronteira ${ }^{24}$. Rafael Chambouleyron foi um dos mais recentes pesquisadores que examinaram a colônia, a atividade missionária e as relações sociais na região da Amazônia no século XVII ${ }^{25}$.

A definição da religião no processo dos contatos missionários tornou-se um enfoque primordial em muitas pesquisas. Em Religião como tradução, Christina Pompa dá uma ênfase especial à "tradução" dos sentidos simbólicos nos esforços dos povos indígenas para transformar o universo. O estudo sobre o próprio zelo missionário se transformou: de filopiedade, tornou-se um estudo sobre interação, fracassos, adaptações e compromissos. The Making of an enterprise (1996), de Dauril Alden, forneceu uma base para as pesquisas sobre os Jesuítas no império português, colocando assim o Brasil dentro de um contexto global.

Novos trabalhos, como o de Castelnau-L'Estoile (2000), abordaram a questão da conversão no período posterior aos grandes sucessos dos

22 RUSSELL-WOOD, A. J. R. "Introduction: New Directions in Bandeirismo Studies in Colonial Brazil”. In: The Americas, v. 61, n. 3, 2005, p. 353-71.

23 SCHWARTZ, Stuart B.; LANGFUR, Hal. "Tapanhuns, Negros da terra, and Curibocas: Indians and Afro-Brazilians in Colonial Brazil” In: Mat Restall (Ed.) Beyond Black and Red. Albuquerque: University of New Mexico Press, 2006, p. 81-115; METCALF, Alida. "Millinarian Slaves? The Santidade de Jaguaripe and Slave Resistance in the Americas". In: AHR, v. 104, n. 5, 1999, p. 531-59. O tema é também abordado em GOMES, Flávio dos Santos. A hydra e os pântanos. Mocambos, quilombos e comunidades de fugitivos no Brasil (séculos XVII-XIX). São Paulo: UNESP, 2005.

24 Por exemplo, KARASCH, Mary. "Rethinking the Conquest of Goiás, 1778-1813”. In: The Americas, v. 61, n. 3, 2005, p. 463-492.

25 Por exemplo, CHAMBOULEYRON, Rafael. "Plantações, sesmarias, e vilas. Uma reflexão sobre a ocupação da Amazônia seiscentista”. In: Nuevo mundo, mundos nuevos, v. 6, Paris: EHESS, online, 2006; "Escravos do Atlântico equatorial: tráfico negreiro para os Estados do Maranhão e Pará (século XVII e início do século XVIII)". In: Revista Brasileira de História, v. 26, 2006, p. 79-114. 
contatos iniciais, quando vitórias eram mais efêmeras e quando o ardor dos missionários e as suas qualidades pessoais não coincidiam mais com a sua missão. $\mathrm{O}$ enfoque foi restrito; passou de uma visão do empreendimento missionário e seus objetivos a realidades quotidianas da vida nas aldeias ${ }^{26}$. Um bom exemplo disso é o trabalho de Celestino de Almeida sobre a maneira como funcionavam as aldeias indígenas no Rio de Janeiro. $\mathrm{O}$ enfoque do trabalho é voltado para a integração dessas aldeias no mercado de trabalho local, assim como a criação de novas identidades, fruto das misturas e das fusões de diversos grupos sob o controle dos missionários. Essa pesquisa evidencia o impulso dos estudos recentes sobre os aspectos culturais e materiais da vida indígena no cenário colonial. Contudo, a adaptação forçada a modelos europeus representa só uma parte desses contatos. João Azevedo Fernandes enfatizou o papel crucial das mulheres Tupinambás, do matrimônio e do parentesco na criação de espaços culturais de interação durante as primeiras gerações de contato ${ }^{27}$.

Estudos sobre os índios e as relações entre os índios e os portugueses no século XVIII foram realizados, sobretudo na região da Amazônia. Mas o estudo o mais ambicioso de todos é, provavelmente, o de Almeida sobre o Diretório e a secularização das missões. Esse trabalho tem seu foco nos estados do Pará e do Maranhão. Angela Domingues, Patricia Melo Sampaio e Barbara A. Sommer também retratam esse período. Essas três pesquisadoras trataram as reformas pombalinas e as suas repercussões radicais sobre as populações indígenas da região ${ }^{28}$. Santos se dedica ao estudo da resistência dos índios às pressões e mudanças de política dos portugueses, enquanto Nadia Farage, numa pesquisa excelente, examina a situação dos povos indígenas nas fronteiras de Rio Branco. Esses povos

26 Aldeamentos paulistas, do geógrafo Pasquale Petrone (São Paulo: EDUSP, 1995), foi escrito em 1965, mas não foi publicado naquela época. O livro fornece uma excelente análise das origens de Santos e de São Paulo como aldeias missionárias.

27 FERNANDES, João Azevedo.De cunhã a mameluca. João Pessoa: Editora Universitária, 2003.

28 DOMINGUES, Angela. Quando os indios eram vassalos. Lisboa: CNCDP, 2002; MELO SAMPAIO, Patrícia Maria. Espelhos partidos: Etnia, legislação e desigualdade na colônia sertões do GrãoPará. Tese (Doutorado) - Universidade Federal Fluminense, 2001; SOMMER, Barbara A. Negotiated Settlements. Native Amazonians and Portuguese Policy in Pará, Brazil, 1758-1798. Thesis (Ph.d.) - University of New Mexico, 2000. 
eram coagidos pela competição entre os regimes coloniais portugueses, holandeses e espanhóis ${ }^{29}$.

Os intercâmbios e os conflitos entre europeus e povos nativos são uma arena ideal para os estudos culturais e as interações culturais. $A$ heresia dos índios (1995), de Ronaldo Vainfas, sobre o fenômeno da "santidade", movimento sincrético religioso de resistência dos índios da Bahia à dominação portuguesa, destacou a fusão dos elementos religiosos. Esse mesmo tema da santidade foi objeto da pesquisa de Alida Metcalf sobre os mediadores culturais no primeiro século de $\operatorname{contatos}^{30}$. Os processos da Inquisição, que serviram de alicerce a esses estudos, ressaltam o sincretismo $\mathrm{e}$ as trocas culturais. No entanto, eles precisam ser contextualizados a partir do gênero particular das confissões de "renegados", nas quais aqueles que voltam para a Igreja sempre relatam que a separação foi devida à necessidade ou adversidade e que a volta se faz em razão da sua convicção.

A guinada cultural possibilitou um novo enfoque sobre vários temas. $\mathrm{O}$ interesse pela linguagem e a sua manipulação encontrou eco nas pesquisas de João Adolfo Hansen sobre a percepção das línguas indígenas e de Bessa Freire nas estratégias linguísticas na Amazônia, assim como a estrutura interpretativa do trabalho de Claudia Pompa sobre interação e catecismo no primeiro século de contato ${ }^{31}$. A representação é outra temática dos historiadores culturais. Ela produziu uma série de novos estudos sobre a maneira dos observadores europeus de descrever, retratar e analisar a América e seus habitantes indígenas ${ }^{32}$.

29 SANTOS, Francisco José dos. Além da conquista. Guerras e rebeliões indígenas na Amazônia pombalina. Manaus: Editora da Universidade de Amazonas, 1999; FARAGE, Nádia. As muralhas dos sertões. Os povos indígenas no Rio Branco e a colonização. Rio de Janeiro: Paz e Terra; ANPOCS, 1991.

30 VAINFAS, Ronaldo. A heresia dos índios. São Paulo: Companhia das Letras, 1996; METCALF, Alida. Go-Betweens and the colonization of Brazil, 1500-1600. Austin: University of Texas Press, 2005.

31 HANSEN, João Adolfo Hansen. "Sem f, sem 1, sem r: Cronistas, jesuítas e índios no século XVI". In: KOSSOVITCH, Elisa A. (Ed.). A conquista da América. Campinas: Cedes, 1993 [Cadernos Cedes 30]; BESSA FREIRE, José Ribamar. Rio babel. Rio de Janeiro: Atlântica Editora, 2004; BESSA FREIRE, José Ribamar; ROSA, Maria Carlota. Línguas gerais. Política linguística e catequese na América do Sul no período colonial. Rio de Janeiro: EDUERJ, 2003.

32 ASSUNÇÃO, Paulo de. A terra dos brasis: natureza da América portuguesa vista pelos primeiros jesuítas (1549-1596). São Paulo: Annablume, 2000; ROMANELI, Ronald Romaneli. Imagens da colonização. São Paulo: Jorge Zahar Editora; EDUSP, 1996; ZIEBELL, Zinka. Terra de canibais. Porto Alegre: Universidade Federal de Rio Grande do Sul, 2002. 
Os povos indígenas foram, frequentemente, tratados da mesma maneira que a flora e a fauna, isto é, como parte da História Natural do Brasil e, assim sendo, um obstáculo ao progresso. A história ambiental está ainda no começo no Brasil, mas o trabalho pioneiro de Warren Dean sobre a mata atlântica, incluindo uma grande parte sobre os habitantes indígenas, está começando a atrair seguidores. José Augusto Pádua elaborou uma pesquisa sobre o pensamento ambiental, cobrindo um período desde o final do século XVIII até a proclamação da República, e Shawn Miller analisou as florestas e o mangue da Bahia sob uma perspectiva ambiental e econômica ${ }^{33}$. Sem dúvida, esse campo de estudos crescerá na próxima década.

\section{Vida e cultura afro-brasileira}

Ao que tudo indica, o centenário da abolição em 1988 foi o auge do interesse dos pesquisadores pela escravidão e pela cultura afrobrasileira. Entretanto, esse campo continuou a prosperar e tomou vários outros rumos, embora sejam os estudiosos do século XIX muito mais ativos que os historiadores da era colonial ${ }^{34}$. Nos anos 1970 e 1980, Robert Slenes, Manolo Florentino, Mary Karasch e Katia Queirós de Mattoso produziram importantes estudos quantitativos e, desde então, seus alunos vêm realizando pesquisas com um forte enfoque regional. Excelentes livros foram publicados nos anos 1980, tais como os trabalhos de Leila Algranti sobre a escravidão urbana no Rio de Janeiro e de Silvia Lara sobre a violência da escravatura em Campos de Goitacases, evidenciando

33 DEAN, Warren. With Broadax and Firebrand. The Destruction of the Brazilian Atlantic Forest. Berkeley: University of California Press, 1995; PÁDUA, José Augusto. Um sopro de destruição. Rio de Janeiro: Jorge Zahar, 2002; MILLER, Shawn. Fruitless Trees. Portuguese Conservation and Brazil's Colonial Timber. Stanford: Stanford University Press, 2000; "Stilt-Root Subsistence: Colonial Mangroves and Brazil's Landless Poor". In: HAHR, v. 83, n. 2, 2003, p. 223-54.

34 Incluí uma bibliografia extensiva de estudos e pesquisas sobre a escravidão no Brasil em SCHWARTZ, Stuart B. Escravos roceiros, e rebeldes. Bauru: EDUSC, 2001, que é uma atualização do trabalho anterior integrante da edição em inglês desse livro que foi publicado em 1988. Limitei meus comentários, neste trabalho, porque o assunto é parte do ensaio de João José Reis e Herbert Klein nesse volume. 
assim a continuidade da tradição ${ }^{35}$. Muitos trabalhos de qualidade sobre a escravidão se concentraram sobre Minas Gerais. Por exemplo, K. Higgins, Licentious Liberty, um estudo sobre a escravatura em Sabará (Minas Gerais), que contém análises de manumissão, compadrio e outros subtemas desenvolvidos durante a expansão da história da escravatura e a guinada para os temas sobre as ações de escravos e a agência. Pode-se citar também, de Eduardo Paiva França, a análise das estratégias dos escravos para se libertarem através de testamentos ou a pesquisa de Douglas Libby sobre manumissão e demografia, ou ainda o trabalho de Donald Ramos sobre a família escrava ${ }^{36}$. A década de 1990 testemunhou a extensão de estudos importantes sobre a mesma temática. O estudo de José Roberto Goes sobre a escravatura na capitania de Rio de Janeiro é uma exploração imaginativa da operação de compadrio e da organização familiar entre os escravos. Mais tarde, esse estudo foi prolongado pelo livro que ele escreveu com M. Florentino ${ }^{37}$. Robert Slenes realizou uma pesquisa semelhante sobre a era imperial em São Paulo, mas com implicações para o período colonial, pois o seu trabalho se orientou, progressivamente, na direção da História Cultural e deixou de ser História sociodemográfica ${ }^{38}$. Estudos primorosos, como os de Elizabeth Kuznesoff e José Flávio Mota sobre São Paulo, e a pesquisa de Sheila Faria de Castro sobre Campos de Goitacases, mostraram a influência invasora da escravidão sobre todos os grupos sociais e sobre a dinâmica da vida colonial ${ }^{39}$.

35 ALGRANTI, Leila Mezan. O feitor ausente. Petrópolis: Vozes, 1988; LARA, Silvia Hunold. Campos de violência. Escravos e senhores na capitania do Rio de Janeiro. Rio de Janeiro: Paz e Terra, 1988.

36 HIGGINS, Kathleen. Licentious Liberty in a Brazilian Gold-Mining Region. University Park, PA: Pennsylvania State University Press, 1999; PAIVA, Eduardo França. Escravos e libertos nas Minas Gerais do século XVIII. São Paulo: Annablume, 1996; LIBBY, Douglas Cole; GRAÇA FILHO, Afonso de Alencastro. "Reconstruindo a liberdade - alforria e forros na freguesia de São José do Rio das Mortes, 1750-1850". In: Varia História, v. 30, 2003, p. 112-151; e FILHOS DE DEUS, Tarcísio R. "Batismos de crianças legítimas e naturais na paróquia de Nossa Senhora do Pilar de Ouro Preto, 1712-1810". In: Varia História, v. 31, 2004, p. 69-97; RAMOS, Donald. "Single and married women in Vila Rica, Brazil, 17541838", In: Journal of Family History, v. 16, n. 3, 1991, p. 261-81.

37 GÓES, José Roberto. O cativeiro imperfeito. Vitória: Governo do Estado de Espírito Santo, 1993; FLORENTINO, Manolo; GÓES, José Roberto. A paz das senzalas. Famílias escravas e tráfico atlântico, c. 1790-1850. Rio de Janeiro: Civilização Brasileira, 1997. Alguns trechos podem ser lidos em inglês em "Slavery, marriage and kinship in rural Rio de Janeiro". In: Paul E. Lovejoy (Ed.). Identity in the Shadow of Slavery. London and New York: Continuum, 2000, p. 137-162.

38 SLENES, Robert W. Na senzala, uma flor. Esperanças e recordações na formação da família escrava. Rio de Janeiro: Editora Nova Fronteira, 1999.

39 KUZNESOFF, Elizabeth. Household Economy and Urban Development: São Paulo, $1765-$ 1836. Boulder, CO: Westview Press, 1986; MOTTA, José Flávio. Corpos escravos, vontades livres. Posse 
Nem todos os trabalhos recentes tiveram como objeto os escravos. Os significados e implicações da escravidão foram objeto de dois estudos importantes de Rafael Marquese sobre a questão do gerenciamento dos escravos e vários outros trabalhos examinaram a importância da cor e da raça na sociedade colonial ${ }^{40}$. Alguns dos mais inovadores trabalhos quantitativos foram realizados sobre Minas Gerais e o Sul do Brasil, tanto sobre a escravidão quanto sobre não-escravos de cor. Laird Bergad produziu um estudo impressionante sobre Minas Gerais; nele, o autor atenuou a visão da escravidão como uma instituição contratual durante o declínio da economia mineira. Já Herbert Klein explorou, independentemente e junto com Clothilde Paiva, a escravatura e os libertos em Minas Gerais e São Paulo. Klein e Francisco Vidal Luna mostraram a importância da escravidão na economia de São Paulo, assim como o fato de que casamentos entre escravos eram muito mais frequentes nessa região que no resto do Brasil e que essa situação teve um grande impacto no status legal e no papel dos libertados nessa regiã $0^{41}$.

Juntamente com a contínua e forte tradição de estudos sociais e econômicos da escravidão como uma instituição e dos escravos como atores humanos, a historiografia da escravidão continuou se expandindo. Assim sendo, a abordagem econômica e política dos historiadores brasileiros adquiriu uma dimensão atlântica. Esse contexto era inerente ao assunto e foi claramente designado na obra primorosa de Charles Boxer intitulada Salvador de Sá and the struggle for Brazil and Angola (1952) e no clássico de Pierre Verger sobre o fluxo de pessoas e de culturas entre a Bahia e o Golfo de Benin (1968). No entanto, graças à publicação de Africa and

de cativos e familia escrava em Bananal (1801-1829). São Paulo: Annablume, 1999; FARIA, Sheila de Castro. A colonia em movimento. Fortuna e familia no cotidiano colonial. Rio de Janeiro: Editora Nova Fronteira, 1998.

40 MARQUESE, Rafael de Bivar. Administração e escravidão - ideias sobre a gestão da agricultura escravista brasileira. São Paulo: HUCITEC, 1999; Feitores do corpo, missionários da mente. Senhores, letrados e o controle dos escravos nas Américas, 1660-1860. São Paulo: Companhia das Letras, 2004.

41 BERGAD, Laird. Slavery and the Demographic and Economic History of Minas Gerais, Brazil, 1720-1888. Cambridge: Cambridge University Press, 1999; KLEIN, Herbert. "A demografia do tráfico atlântico de escravos para o Brasil". In: Estudos Econômicos, v. 17, n. 2, 1987, p. 129-50; e PAIVA, Clothilde. "Slave And Free in Nineteenth-Century Minas Gerais, Campanha, 1831". In: Slavery and Abolition, v. 15, n. 1, 1994, p. 1-21; LUNA, Francisco Vidal; KLEIN, Herbert. Slavery and the Economy of São Paulo, 1750-1850. Stanford: Stanford University Press, 2003. 
Africans, de John Thornton, de Way of Death, de Joseph Miller, e Trato dos viventes, de Luiz Felipe Alencastro, uma nova legitimidade foi atribuída à integração do Atlântico-Sul português. Nessa parte do mundo, os escravos transitavam, continuamente, da África para o Brasil, os administradores circulavam do Brasil para a África e políticas imperiais eram, geralmente, elaboradas com uma atenção especial à interdependência das duas esferas coloniais $^{42}$. Obviamente, a dimensão Atlântico-Sul se manifesta também nos estudos mais recentes sobre o comércio de escravos, como na obra De costa a costa, de Jaime Rodrigues (2005), que trata das tripulações (de escravos e de homens livres) nas embarcações envolvidas no comércio de escravos entre a Angola e o Brasil. Pode ser feito um paralelo entre esse livro e a obra de Marcus Rediker e Peter Linebaugh sobre o AtlânticoNorte $^{43}$. Esta dimensão atlântica também é um aspecto fundamental da nova História Cultural ligada a estudos da diáspora africana e afroamericana. Grande parte desse trabalho foi centrada na demonstração da transferência e da persistência de etnias específicas africanas, religiões ou práticas culturais e uma rejeição da criolização como uma maneira mais vantajosa de conceituar a formação da cultura afro-brasileira ${ }^{44}$. Daniela

42 BOXER, Charles R. Salvador de Sá and the Struggle for Brazil and Angola. London: University of London/Athlone Press, 1952; VERGER, Pierre. Flux et reflux la traite des nègres entre le golfe de Bénin et Bahia de Todos os Santos du XVII au XIX siécle. Paris: Mouton, 1968, edição brasileira, 1987; THORNTON, John. Africa and Africans in the Making of the Atlantic World. 2. ed. Cambridge: Cambridge University Press, 1998; MILLER, Joseph. Way of Death. Merchant Capitalism and the Angolan Slave Trade, 1730-1830. Madison: University of Wisconsin Press, 1988; ALENCASTRO, Luiz Felipe de. O trato dos viventes. Formação do Brasil no Atlântico sul. Séculos XVI e XVII. São Paulo: Companhia das Letras, 2000. Um resumo de suas ideias pode ser encontrado em "Le versant brésilien de l'Atlantique-sud: 1550-1850". In: Annales. Histoire, Sciences Sociales, v. 61, n. 2, 2006, p. 339-382. Ver, também, COSTA E SILVA, Alberto. Um rio, chamado Atlântico. A África no Brasil e o Brasil na África. Rio de Janeiro: Editora Nova Fronteira, 2003.

43 RODRIGUES, Jaime. Da costa a costa. Escravos, marinheiros e intermediários do tráfico negreiro de Angola ao Rio de Janeiro (1780-1860). São Paulo: Companhia das Letras, 2005; O infame comércio. Propostas e experiências no final do tráfico de africanos para o Brasil. Campinas: Unicamp, 2000. Cf. REDIKER, Marcus. Between the Devil and the Deep Blue Sea. Cambridge: Cambridge University Press, 1989; LINEBAUGH, Peter; REDIKER, Marcus. The Many-Headed Hydra: Sailors, Slaves, Commoners, and the Hidden History of the Revolutionary Atlantic. Boston: Beacon Press, 2000.

44 Existem excelentes artigos sobre as influências culturais da África Central no Brasil em HEYWOOD, Linda M. Central African Cultural Transformations in the American Diaspora. Cambridge, 2002. Cf., por exemplo, KARASCH, Mary. Central Africans in Central Brazil,p. 117-152; KIDDY, Elizabeth W. Who is the king of the Congo? A New Look at African and Afro-Brazilian Kings in Brazil,p. 153-182; SLENES, Robert. The Great Porpoise-Skull Strike: Central African Water Spirits and Slave Identity in Early Nineteenth-Century Rio de Janeiro, p. 183-210. Para ler uma abordagem africanista, Cf. LOVEJOY, Paul 
Calainho e, em menor escala, James Sweet, usam casos da Inquisição envolvendo bruxaria e heresia para desvendar práticas africanas, embora seja muito difícil diferenciar entre as origens africanas ou europeias de certos talismãs e ritos de adivinhação ${ }^{45}$. O estudo de João José Reis sobre a revolta dos Malês em 1835, e os seus trabalhos subsequentes, mantiveram a tradição baiana com os aspectos da cultura africana no Brasil, mas foi usado como ponto de partida e serviu de exemplo para a recente onda de interesse pelo tema ${ }^{46}$. Entre os melhores estudos, pode-se citar Devotos de cor, de Mariza de Carvalho, sobre as irmandades negras Mina (de língua iorubá) no Rio de Janeiro e de outros grupos étnicos e religiosos ${ }^{47}$. Enquanto esses estudos ajudaram a melhor entender os aspectos africanos da cultura afro-brasileira, às vezes confirmaram, com entusiasmo mas sem provas, a permanência dessas características, e se obstinaram em não reconhecer que outras identidades "coloniais" baseadas na cor, no status ou no lugar de nascimento assumiam uma grande importância nas associações étnicas africanas. Os pontos de vista africanistas vs. os pontos de vista crioulos fornecem, às vezes, a base de estratégias interpretativas bastante diferentes. Por exemplo, a pesquisa de Marina de Mello e Souza sobre as tradições

E. "The African Diaspora: Revisionist Interpretations of Ethnicity, Culture and Religion under Slavery". In: Studies in the World History of Slavery, Abolition, and Emancipation, v. 2, 1997, p. 1-23. Richard Price caracterizou e criticou essa nova ênfase "africanista" como sendo uma perspectiva "nacionalista cultural". Ver PRICE, Richard. "The Miracle of Creolization: A Retrospective". In: New West Indies Guide, v. 75, n. 1-2, 2001, p. 35-64.

45 CALAINHO, Daniela. Metrópole das mandingas: Religiosidade negra e Inquisição portuguesa no antigo regime. Tese (doutorado) - Universidade Federal Fluminense, 2000; SWEET, James. Recreating Africa: Culture, Kinship, and Religion in the African Portuguese World, 1441-1770. Chapel Hill, NC: University of North Carolina Press, 2003. Ver, também, MIDLO HALL, Gwendolyn. Slavery and African Ethnicities in the Americas. Chapel Hill: University of North Carolina Press, 2005; GOMEZ, Michael A. Reversing Sail. A History of the African Diaspora. Cambridge: Cambridge University Press, 2005; e como organizador, Diasporic Africa. A Reader. New York: New York University Press, 2006.

46 REIS, João José. Rebelião escrava no Brasil. A história do levante dos Malês. São Paulo: Brasiliense, 1986; 2. ed. São Paulo: Companhia das Letras, 2004; "Magia jejê na Bahia: A invasão do calundu do Pasto de Cachoeira, 1785". In: Revista Brasileira de História, v. 8, n. 16, 1988, p.57-82; "African Drumming and Dance between Repression and Concesión: Bahia, 1808-1855”. In: GOMEZ, M. (Ed.). Diasporic Africa, p. 45-63.

47 SOARES, Mariza de Carvalho. Devotos de cor. Identidade étnica, religiosidade e escravidão no Rio de Janeiro, século XVII. Rio de Janeiro: Civilização Brasileira, 2000; "From Gbe to Yoruba: Ethnic Changes within the Mina Nation in Rio de Janeiro". In: FAROLA, Tony; CHILDS, Matt (Eds.). The Yoruba Diaspora in the Atlantic World. Bloomington: Indiana University Press, no prelo. Esses estudos são baseados nas fundações sólidas das irmandades laicas em Minas Gerais, como BOSCHI, Caio César. Os leigos e o poder. São Paulo: Ática, 1986; SCARANO, Julieta. Devoção e escravidão. São Paulo: Ed. Nacional, 1976. 
das várias irmandades negras nas coroações de Reis e Rainhas Kongo. Sua investigação das raízes dessa prática no Brasil se concentra na história do reino Kongo e seus contatos com o catolicismo português. Mas E. Kiddy demonstra, na sua pesquisa sobre as irmandades do Rosário, em Minas Gerais que, sem que as influências africanas sejam descartadas, essa prática remonta à tradição católica associada ao próprio culto de Nossa Senhora do Rosário, e não à África, e que o critério para pertencer a essas irmandades mineiras era a cor e não a etnicidade africana. O livro a ser publicado, de Silvia Lara, mostra como a religiosidade e os rituais dos afro-brasileiros nas irmandades e nas coroações de reis e rainhas podem ser incluídos numa discussão mais ampla da História Cultural brasileira ${ }^{48}$.

Esse interesse renovado por escravos e seus descendentes enquanto agentes históricos e o interesse da História Cultural pela identidade e a representação resultaram em várias obras reconstruindo as vidas de indivíduos afro-brasileiros e, consequentemente, as relações sociais e as crenças do tempo em que eles viveram. A biografia de um profeta de rua negro desconhecido e "santo" popular, radicado no Rio de Janeiro do século XVIII, por Luis Mott, e a obra de Junia Furtado sobre a figura famosa e mítica de Chica da Silva, "rainha" do distrito dos diamantes de Minas Gerais, são exemplos notáveis da interseção entre biografia, micro-história e abordagens culturais com a História Social ${ }^{49}$.

\section{História Social e Cultural}

O crescente interesse pela História Cultural não se limita aos estudos sobre os índios ou os africanos. Desde os anos 1980. a mesma foi usada, primeiramente, como um subsidiário da História da sociedade brasileira e, depois, como um método ou uma abordagem em si. A nova

48 LARA, Silvia Hunold. Fragmentos setecentistas: Escravidão, cultura e poder na América portuguesa. Tese (Livre Docência) - Universidade de Campinas, 2004.

49 MOTT, Luiz. Rosa Egipcíaca: uma santa africana no Brasil. Rio de Janeiro: Bertrand, 1993; FURTADO, Júnia Ferreira. Chica da Silva e o contratador dos diamantes. São Paulo: Companhia das Letras, 2003. 
historiografia tenta romper com as interpretações estruturalistas e espera desvendar a agência humana daquelas pessoas com um acesso limitado ao poder, tais como escravos, mulheres ou negros livres e, por isso, teve a possibilidade de investigar novas direções. Ao mesmo tempo, essa nova historiografia permitiu que os historiadores reconsiderassem importantes questões tradicionais dentro de uma nova perspectiva. Por exemplo, a questão do poder local e a formação de elites regionais dentro do sistema imperial. Em sete monografias esplêndidas, o ex-diplomata Evaldo Cabral de Mello escreveu a história de Pernambuco, focalizando-se sobre os eventos mais importantes (a ocupação holandesa, 1630-54; a Guerra dos Mascates, 1711-13; os movimentos para a independência, 1817-1824), mas a sua preocupação maior foi com a autoconsciência e a autorrepresentação dos plantadores que formavam a classe dominante da região. O objeto privilegiado da sua pesquisa remete mais à mentalidade e à autoprojeção da imagem dessa classe que ao governo ou às instituições. No entanto, a economia regional e as estruturas governamentais fazem sempre parte das suas preocupações. Os textos de Cabral de Mello, tomados como um corpus, devem ser vistos como uma das principais realizações historiográficas das últimas duas décadas e uma demonstração efetiva da relação entre História Cultural, Social e Política.

Importantes trabalhos foram produzidos nas duas últimas décadas dentro dos contextos tradicionais do conhecimento acadêmico do século XX. Os estudos sobre a configuração política do Brasil e o seu lugar dentro do contexto das rivalidades imperiais do século XVII evoluíram graças ao ressurgimento do interesse pela união da Espanha e de Portugal (1580-1640) e as suas implicações imperiais ${ }^{50}$. Pesquisas sobre a economia brasileira continuam a se desenvolver. No que diz respeito ao século XVII, a obra de Christopher Ebert sobre o comércio do açúcar e a pesquisa fundamental

50 Ver, por exemplo, SCHAUB, Jean Frédéric. Le Portugal au temps du comte-duc de Olivares (1621-1640). Madrid: Casa de Velázquez, 2001; Portugal na monarquia hispânica, 1580-1640. Lisboa: Livros Horizonte, 2001; VALLADARES, Rafael. La rebelión de Portugal, 1640-1680. Madrid: Junta de Castilla y León, 1998; ALVAREZ, Fernando Bouza. Portugal en la monarquía hispánica (1580-1640). Madrid: Universidad Complutense, 1987; SERRÃO, Joaquim Veríssimo. O tempo dos Filipes em Portugal e no Brasil (1580-1668). Lisboa: Edições Colibrí, 1994; VENTURA, Maria da Graça M. (Ed.). A união ibérica e o mundo Atlântico. Lisboa: Edições Colibrí, 1997; SCHWARTZ, Stuart B. "The Voyage of the Vassals: Royal Power, Noble Obligations, and Merchant Capital before the Portuguese Restoration of Independence, 1624-1640”. In: American Historical Review, v. 96, n. 3, 1991, p. 735-62. 
de Leonor Freire Costa sobre a organização e as frotas da Companhia do Brasil destacam a importância do comércio mercantil e dos negociantes em relação ao papel do Brasil no império. Já Daviken Studnicki-Gizbert mostra o impacto dos negociantes portugueses no mundo atlântico mais amplo ${ }^{51}$. No que diz respeito ao século XVIII, uma excelente coletânea organizada por Júnia Furtado contém vários artigos associando Minas Gerais ao sistema atlântico mais amplo de comércio e política. Já a sua própria monografia tinha analisado a vida e as atividades de um negociante daquele período ${ }^{52}$. As obras de Novais, Arruda, Valentim e Pedreira sobre a economia do Atlântico são essenciais para o debate interpretativo sobre o fim do regime colonial no Brasil, que se encontra abaixo.

Leis e instituições jurídicas também mereceram um interesse renovado. Meu próprio volume de História Social sobre a Relação da Bahia e seus desembargadores pode agora se juntar ao estudo paralelo de Arno e Maria José Wehling sobre a Relação do Rio de Janeiro. Nele, é feita uma investigação muito mais aprofundada das questões e das origens do direito português. G. Pereira das Neves trata da operação da Mesa da Consciência, o conselho português sobre os assuntos religiosos no contexto do deslocamento da Corte portuguesa para o Brasil ${ }^{53}$.

Questões de prática e de cultura jurídica são também primordiais no estudo em dois volumes de Linda Lewin, cuja temática é a legislação sobre herança e suas mutações ${ }^{54}$. A relação de escravos e libertos com a lei e as instituições jurídicas foi examinada por Russell-Wood, mas ainda aguarda

51 EBERT, Christopher. The Trade in Brazilian Sugar: Brazil, Portugal, and Northwestern Europe, 1550-1630. Thesis (Ph.d.) - Columbia University, 2004; COSTA, Leonor Freire. O transporte no Atlântico e a Companhia Geral do Comércio do Brasil, 1580-1663, 2 v. Lisboa: Comissão Nacional para as Comemorações dos Descobrimentos Portugueses, 2002; Império e grupos mercantis. Entre o Oriente e o Atlântico (século XVII). Lisboa: Livros Horizonte, 2002; STUDNICKI-GIZBERT, Daviken. A Nation upon the Ocean Sea. Portugal's Atlantic Diaspora and the Crisis of the Spanish Empire, 1492-1640. New York: Oxford University Press, 2006.

52 FURTADO, Júnia (Ed.). Diálogos oceânicos. Minas Gerais e as novas abordagens para uma história do Império Ultramarino Português. Belo Horizonte: Editora UFMG, 2001; Homens de negócio: a interiorização da metrópole e do comércio nas Minas setecentistas. São Paulo: HUCITEC, 1999.

53 SCHWARTZ, Stuart B. Bureaucracy and Society in Colonial Brazil. Berkeley: University of California Press, 1978; WEHLING, Arno; WEHLING, Maria José. Direito e justiça no Brasil colonial. O tribunal da Relação do Rio de Janeiro (1751-1808). Rio de Janeiro: Renovar, 2004; NEVES, G. Pereira das. E receberaì mercê: a Mesa da Consciência e Ordens e o clero secular no Brasil, 1808-1828, s.d.

54 Acadêmicos têm agora à sua disposição um site que disponibiliza as coleções de legislações portuguesas para o início do período moderno. Consultar: <www.iuslusitaniae.fcsh.unl.pt $>$. Ius Lusitaniae. Fontes Históricas do Direito Português. 
um estudo mais aprofundado ${ }^{55}$. Ninguém ainda abordou a grande coleção de processos judiciais que se encontram no Arquivo dos Feitos Findos em Lisboa, que contém um significativo material sobre Brasil.

A história urbana vem merecendo um interesse contínuo a partir de várias abordagens. É bem representada por Nireu Cavalcanti no estudo sobre a construção, forma e organização social do Rio de Janeiro do século XVIII, assim como por um estudo detalhado do desenvolvimento e da construção de Recife sob o domínio holandês, por Nederveen Merkerk. A pesquisa da falecida Ilana Blaj sobre as redes de poder e de comércio na transformação de São Paulo em centro regional importante mostra que o acesso aos trabalhadores indígenas e ao mercado interno foi um fator decisivo nesse processo $^{56}$. O governo do Rio de Janeiro é o foco do trabalho de Fernanda Bicalho e Maria da Fátima Gouvêa, que o utilizaram como perspectiva para analisar a questão do poder municipal e do governo imperial, em geral ${ }^{57}$. Pequenas cidades também têm os seus historiadores. O estudo-modelo de Laurent Vidal sobre a cidade e os habitantes de Mazagão, um posto avançado no Marrocos e transplantado no Amazonas, é uma verdadeira odisseia atlântica. Nestor Goulart Reis estendeu as suas contribuições nessa área com a publicação de um volume contendo plantas e vistas de cidades coloniais $^{58}$. O estudo detalhado de Cláudia Damasceno Fonseca sobre a formação da rede urbana de Minas Gerais e o uso do espaço dentro das cidades faz a ligação entre as análises sociais e geográficas ${ }^{59}$. Instituições urbanas também ganharam uma atenção renovada. C.R. Boxer utilizou

55 RUSSELL-WOOD, A.J.R. "Vassalo e soberano: Apelos extrajudiciais de africanos e de indivíduos de origem africana na América portuguesa". In: NIZZA DA SILVA, Maria Beatriz (Ed.). Cultura portuguesa na terra de Santa Cruz. Lisboa: Editorial Estampa, 1995, p. 215-33.

56 BLAJ, Ilana. A trama das tensões. O processo de mercantilização de São Paulo colonial (1681-1720). São Paulo: Universidade de São Paulo, 2002.

57 Ver BICALHO, Maria Fernanda B. "As câmaras municipais no império português: O exemplo do Rio de Janeiro". In: Revista Brasileira de História, v. 18, n. 36, 1998, p. 251-80; GOUVÊA, Maria de Fátima. "Redes de poder na América portuguesa - o caso dos homens bons do Rio de Janeiro, ca. 1790-1822”. In: Revista Brasileira de História, v. 18, n. 36, 1998, p. 297-330.

58 MEERKERK, Hannedea van Nederveen. Recife: The rise of a 17th Century trade city from a cultural-historical perspective. Assen, The Netherlands: Van Gorcum, 1989; CAVALCANTI, Nireu. $O$ Rio de Janeiro setecentista. Rio de Janeiro: Jorge Zahar Editor, 2004; VIDAL, Laurent. Mazagão. La ville qui traversa l'Atlantique. Paris: Aubier, 2005; REIS, Nestor Goulart. Imagens de Vilas e Cidades do Brasil Colonial. São Paulo: Editora da Universidade de São Paulo, Brasil, 2000.

59 FONSECA, Cláudia Damasceno. Des terres aux villes de l'or. Paris: Centre Culturel Calouste Gulbenkian, 2003. 
Salvador no seu estudo comparativo entre as câmaras das diferentes partes do império do Portugal, e Isabel dos Guimarães Sá realizou uma pesquisa semelhante sobre as irmandades caritativas da Misericórdia espalhadas por toda parte do Império Português. Nesse livro, Guimarães Sá se baseia na obra clássica de Russell-Wood ${ }^{60}$.

A história das grandes propriedades está, lentamente, saindo da sombra da interpretação cultural que Gilberto Freyre faz a partir da varanda da fazenda. O açúcar é objeto importante de pesquisas, especialmente na Bahia. O estudo realizado por Vera Ferlini sobre os lavradores de cana abriu novos caminhos. Meu próprio livro sobre a sociedade açucareira baiana foi uma tentativa de deixar de lado uma visão da história focalizando plantadores para examinar outras classes rurais. B.J. Barickman ampliou o objeto da sua pesquisa sobre a história baiana até o século XIX para incluir relações sociais no contexto de outros tipos de agriculturas. O Estado de Pernambuco, exceto no período holandês, não se beneficiou da mesma atenção. Um estudo importante, embora um pouco subestimado, sobre a cultura e o comércio do tabaco, escrito por Jean Baptiste Nardi, revela que muito resta a ser pesquisado em relação a atividades econômicas, fora as açucareiras. Por exemplo, os curtumes - ou seja, a primeira indústria do Brasil colonial - nunca foram analisados. Mas, mesmo assim, os grandes latifúndios e suas gerações de latifundiários têm fascinado alguns historiadores, como mostra o livro de Moniz Bandeira sobre as terras de Garcia D’Ávila ${ }^{61}$.

Talvez um dos mais importantes desenvolvimentos na História Social seja a preocupação com os setores pobres, não-escravos, da população. O livro que representa um marco a esse respeito é Os desclassificados do ouro (1982), de Laura de Mello e Souza. Nele, a autora examina os pobres de Minas Gerais, na época da opulência, e a quarta edição já

60 SÁ, Isabel dos Guimarães. Quando o rico se faz pobre: Misericórdias, caridade e poder no império português, 1500-1800. Lisboa: CNCDP, 1997. Cf. RUSSELL-WOOD, A.J.R. Fidalgos and Philanthropist: The Santa Casa da Misericórdia of Bahia, 1550-1755. Berkeley: University of California Press, 1968. Ver também, Universo urbanístico português, 1415-1822. Lisboa: CNCDP, 1998, que contém artigos escritos por Nelson Goulart Reis e Roberta Delson sobre questões urbanas brasileiras.

61 AMARAL, Vera Lucia Ferlini. Terra, trabalho e poder. São Paulo: Brasiliense, 1988; SCHWARTZ, Stuart B. Sugar Plantations in the Formation of Brazilian Society, Bahia, 1550-1835. Cambridge: Cambridge University Press, 1985; BARICKMAN, B.J. A Bahian Counterpoint. Sugar, tobacco, cassava, and slavery in the Recôncavo, 1780-1860. Stanford: Stanford University Press, 1998; MONIZ BANDEIRA, Luiz Alberto Moniz Bandeira. O feudo. A casa da Torre de Garcia d'Ávila. Rio de Janeiro: Civilização Brasileira, 2000. 
foi publicada. No entanto, outros pesquisadores, tais como Iraci Nero da Costa e Maria Luiza Marcilio, analisaram a população livre e liberta, utilizando os recenseamentos e outras fontes quantitativas para estudar a população rural brasileira. No contexto do Brasil, no entanto, esses estudos sempre levantaram a questão da relação entre trabalho escravo e livre e entre camponeses e escravos. A complexidade desses relacionamentos, a banalidade da possessão de escravos por pessoas relativamente pobres ou por ex-escravos e o impacto, a longo prazo, da economia de exportação, levantaram questionamentos sobre o conceito de "subalternidade" no contexto de uma sociedade escravagista racialmente dividida ${ }^{62}$.

Espaço privado e outros temas, como família, gênero e sexualidade são os principais objetos da relação estreita entre a História Social e a História Cultural. A pesquisa imaginativa de Muriel Nizzari mostra que as mudanças relativas ao dote na São Paulo colonial é uma maneira de avaliar as mudanças no status das mulheres. O mesmo pode ser dito sobre o estudo de Alida Metcalf sobre as mudanças na estrutura familiar das comunidades na área de fronteira de Santana de Parnaíba. As obras sobre história familiar de Mesquita, Marcilio e Nizza da Silva surgiram a partir da tradição das ciências sociais $^{63}$. Mas os temas de gênero e sexualidade levantaram questionamentos sobre atitudes e representações, bem como sobre leis, normas e práticas. Ronaldo Vainfas escreveu uma obra fundamental sobre sexualidade e vida íntima e Luiz Mott publicou uma série de obras sobre lesbianismo, homossexualismo, pederastia e outros aspectos de uma sexualidade dita "desviante" que é particularmente sensível à interação com assimetrias

62 Ver COSTA, Iraci del Nero da. Arraia-miúda: Um estudo sobre os não proprietários de escravos. São Paulo: MGSP Editores, 1992; MARCÍLIO, Maria Luiza. Crescimento demográfico e evolução agrária paulista. 1700-1836. São Paulo: Hucitec, 2000; BARICKMAN, Bert. "A Bit of Land they call roça: Slave Provision Grounds in the Bahian Recôncavo, 1780-1860". In: HAHR, v. 74, n. 4, 1994, p. 469-87; SCHWARTZ, S. B. Peasants, Slaves, and Rebels. Existem bons estudos sobre Pernambuco que tratam desses assuntos. Ver, por exemplo, PALACIOS, Guillermo. Cultivadores libres, Estado y crisis de la esclavitud en Brasil en la época de la Revolución Industrial. Mexico City: Colegio de México y Fondo de Cultura Económica, 1998; SILVA, Kalina Vanderlei. O miserável soldo e a boa ordem da sociedade colonial: militarização e marginalidade na Capitania de Pernambuco dos séculos XVII e XVIII. Recife: Prefeitura do Recife, Secretaria da Cultura, Fundação de Cultura Cidade do Recife, 2001.

63 MESQUITA, Eni de. Família e grupos de convívio. São Paulo: Marco Zero, 1989; As mulheres, o poder e a família. São Paulo: Marco Zero, 1989; MARCÍLIO, Maria Luiza. Crescimento demográfico e evolução agrária paulista: 1700-1836. São Paulo: EDUSP, 2000; NIZZA DA SILVA, Maria Beatriz. História da família no Brasil Colonial. Rio de Janeiro: Nova Fronteira, 1998. 
de classe e raça ${ }^{64}$. Em 1993, Luciano Figueiredo publicou, na tradição das ciências sociais, uma excelente obra, bem detalhada, sobre a sexualidade e o papel das mulheres de classe baixa na economia de Minas Gerais. No mesmo ano, Leila Algranti escreveu um livro sobre a ideologia e a vida interior das mulheres enclausuradas e Mary del Priore, no seu livro Ao sul do corpo, abordou as atitudes sociais e teológicas em relação ao corpo da mulher e também em relação às percepções das próprias mulheres ${ }^{65}$. Desde então, a história das mulheres se tornou um campo de crescente complexidade, como mostra a competente pesquisa de Nizza da Silva ${ }^{66}$.

A religiosidade é uma área onde abordagens culturais têm um impacto particularmente importante. A História das Religiões já não é mais uma mera história institucional da Igreja ou das atividades missionárias. O conceito de religião "popular", enquanto aspecto de uma putativa "cultura popular", tornou-se um grande foco da teoria. É cada vez mais claro que a primeira formulação de uma "religião popular", distinta de um culto oficial, era um conceito simples e rudimentar demais. De fato, existiam diferenças entre a religião prescrita e a religião praticada, e essas variações se traduziam em termos de região ou de classe e, por vezes até, em termos de mudanças ao longo do tempo ${ }^{67}$. Influenciados pelo pensamento de Roger Chartier, Peter Burke, Adriano Prosperi e Carlo Ginzburg, os pesquisadores do passado brasileiro estão, agora, escrevendo um tipo de História das Religiões muito mais completo e integrado. Podemos começar com algumas análises essenciais ${ }^{68}$. Os capítulos de Caio Boschi intitulados

64 MOTT, Luiz. Escravidão, homossexualidade e demonologia. São Paulo: Ícone, 1988; $O$ lesbianismo no Brasil. Porto Alegre: Mercado Aberto, 1987.

65 FIGUEIREDO, Luciano. O avesso da memória. Cotidiano e trabalho da mulher em Minas Gerais no século XVIII. Rio de Janeiro: José Olympio Editora, 1993; ALGRANTI, Leila Mezan. Honradas e devotas: Mulheres da Colônia. Rio de Janeiro: José Olympio Editora, 1993; DEL PRIORE, Mary. Ao sul do corpo: Condição feminina, maternidades e mentalidades no Brasil colônia. Rio de Janeiro: José Olympio Editora, 1993.

66 NIZZA DA SILVA, Maria Beatriz. Donas e plebéias na sociedade colonial. Lisboa: Editorial Estampa, 2002. Ver também o volume Sexualidade, família e religião na colonização do Brasil. Lisboa: Livros Horizonte, 2001.

67 Para uma discussão interessante sobre os elementos da religião popular, ver BADONE, Ellen (Ed.). "Introduction”. Religious Orthodoxy and Popular Faith in European Society. Princeton, 1990, p. 3-23. Ver, também, RODRIGUEZ, Luis E. San Pedro, José Luis Sánchez-Lora Los siglos XVI-XVII. Historia de España Tercer Milenio. Madrid, 2000, p. 207-55.

68 Dois remarcáveis estudos da recente historiografia das religiões em Portugal e no Brasil podem ser encontrados em SÁ, Isabel dos Guimarães. "História religiosa em Portugal e no Brasil: Algumas 
"O enquadramento religioso", sobre a administração eclesiástica, a atividade missionária, ordens religiosas, a Inquisição, a religiosidade laica, na História da expansão portuguesa, v. 2 e 3 (1998), agora proporcionam um excelente ponto de partida para a história religiosa do império, especialmente a católica. Podemos acrescentar a esses volumes a obra fundamental intitulada História religiosa de Portugal, que contém excelentes artigos sobre a instituição da Igreja e sua relação com o Estado, e sobre os espaços, a sociabilidade e as práticas religiosas populares, ou seja, "O Deus de todos os dias". Esses trabalhos gerais servem de ponto de partida e a eles podemos acrescentar: "Cotidiano e vivência religiosa: entre a capela e o calundu", do autor Luiz Mott em História da vida privada (v. 1, 1997), como também os capítulos da mesma coletânea, escritos por Mary del Priore e Ronaldo Vainfas, que tratam do sincretismo e das práticas e costumes específicos do Brasil ${ }^{69}$. Juntos, estes ensaios são uma excelente introdução às várias dimensões da vida religiosa colonial.

A velha divisão entre o catolicismo normativo europeu e, nas áreas coloniais, sua variante, incutida pelos missionários entre os povos "selvagens", é objeto de reformulação. Sabemos, agora, que a transferência do catolicismo postrentino para o laicismo europeu em lugares como Beira Baixa, Galícia e Apulia foi, muitas vezes, frustrante e difícil, como as tentativas de inculcar a prática ortodoxa nas missões do alémmar, e, em alguns aspectos, não muito diferente da conversão dos pagãos do México ou do Maranhão ${ }^{70}$. Como já foi destacado antes, a História das Missões no Brasil cresceu bastante nos últimos anos. E, em particular, as ordens missionárias, e acima de todas, a História dos Jesuítas tem evoluído muito. A obra monumental, exaustiva e vasta de Dauril Alden, The Making of an Enterprise, nos dá uma visão ampla, de dimensões imperiais, da Companhia de Jesus no mundo português. Têm também havido muitos

perspectivas (séculos XVI-XVIII)". In: ARRUDA, José Jobson; FONSECA, Luís Adão da. (Orgs.). BrasilPortugal: História, agenda para o milênio. Bauru, 2001, p. 29-54; e no mesmo volume, VAINFAS, Ronaldo. "História da cultura e das religiosidades no império colonial português (séculos XV-XVIII)", p. 97-106. Ver, também, MANCUSO, Lara; TORRES-LODOÑO, Fernando. "Los estudios sobre lo religioso en Brasil: un balance historiográfico". In: Istor, v. 9, 2002, p. 55-81.

69 VAINFAS, Ronaldo. Moralidades brasílicas: deleites sexuais e linguagem erótica na sociedade escravista, p. 221-273; DEL PRIORE, Mary del. Ritos da vida privada, p. 276-330.

70 DELUMEAU, Jean. Catholicism betweeen Luther and Voltaire: A New View of the CounterReformation. London: Burns and Oates, 1977; PROSPERI, Adriano. Tribunali de cosciencia. Inquisitori, confessori, tribunali. Torino: Einaudi, 1996. 
estudos sobre determinadas áreas e períodos, como aquele de CastelnauL'Estoile, ou a pesquisa de José Eisenberg sobre a ideologia política das missões jesuitícas brasileiras ${ }^{71}$. As outras ordens brasileiras - Carmelitas, Beneditinos, Franciscanos e outras - não mereceram tanta atenção.

A importância do assunto da fusão, da justaposição e do sincretismo religiosos testemunhou uma explosão virtual no Brasil. Dois livros fundamentais de Laura de Mello sobre a religião popular, a bruxaria e o diabo demonstram como uma visão europeia (o olhar) dos Inquisidores foi imposta à realidade multicultural americana ${ }^{72}$. O seu trabalho é ainda mais inteligível graças aos excelentes estudos de J. Paiva e F. Bethencourt sobre o conceito de bruxaria no Portugal metropolitano. A obra de Paiva é especialmente importante porque assinala que muitas práticas condenadas pela Igreja foram perseguidas pelos tribunais episcopais mais que pela Inquisição, de tal modo que bruxaria e magia eram, na realidade, problemas muito mais generalizados do que as estatísticas da Inquisição poderiam levar a $\mathrm{crer}^{73}$.

Hoje em dia temos à nossa disposição estudos rigorosos sobre as práticas religiosas sincréticas no Brasil, como A heresia dos índios (1995), de Vainfas, sobre santidade, um movimento anticolonial messiânico entre os Tupinambás e alguns mamelucos no final do século XVI e início do século XVII na Bahia, ou The Kongolese Saint Anthony, de John Thornton, que trata do movimento restauracionista sincrético liderado por uma mulher congolesa, Dona Beatriz Kimpa Vita, no final do século 17. O trabalho de Thornton também é importante porque nos lembra que uma perspectiva transatlântica imperial ou europeia não é o único requisito para se entender as dimensões da hibridez e da religiosidade. Essas influências, como as pessoas, eram capazes de se deslocar de uma região do império para outra ${ }^{74}$.

71 ALDEN, Dauril. The Making of an Enterprise.The Society of Jesus in Portugal, its empire, and beyond, 1540-1750. Stanford, 1996; CASTELNAU-L'ESTOILE, Charlotte de. Les ouvriers d'une vigne stérile. Les jésuites et la conversion des Indiens au Brésil. Lisbonne/Paris, 2000; EISENBERG, José. As missões jesuíticas e o pensamento político moderno. Belo Horizonte, 2000.

72 MELLO E SOUZA, Laura de Mello e Souza. O diabo e a terra da Santa Cruz. São Paulo, 1986; Inferno atlântico. São Paulo, 1993.

73 BETHENCOURT, Francisco. O imaginário da magia. Lisboa, 1987; PAIVA, José Pedro. Práticas e crenças mágicas. O medo e a necessidade dos mágicos na diocese de Coimbra (1650-1740). Coimbra, 1992, e Bruxaria e superstição num país sem "caça às bruxas" (1600-1774). 2. ed. Lisboa, 2002. Um livro útil é: ARAÚJO, Maria Benedita. Magia, demônio e força mágica na tradição portuguesa (séculos XVII e XVIII). Lisboa, 1994.

74 SCARANO, Julita. Devoção e escravidão. São Paulo, 1976; SOARES, Mariza de Carvalho. Devotos da cor. Identidade étnica, religiosidade e escravidão no Rio de Janeiro, século XVIII. Rio de Janeiro, 
A História Cultural da religião popular é baseada nos trabalhos de Emile Durkheim e de Clifford Geertz, que enfatizaram a cerimônia, o ritual e o espetáculo como demonstrações de projetos de realidade social e de possibilidades sociais. Vale lembrar que uma atenção especial às considerações econômicas e sociais pode ser especialmente útil. A crescente urbanização e riqueza em cidades como Salvador, Ouro Preto e Rio de Janeiro possibilitaram a elaboração estética e cultural de tradicionais festas religiosas e laicas, tais como procissões de celebração de santos ou entradas vice-reais. Nesse sentido, religião popular e História político-administrativa foram estreitamente ligadas ao longo do processo histórico ${ }^{75}$. Mary del Priore fez uma curta introdução sobre esses festivais públicos e os dois volumes fundamentais de Festa (2001), organizados por I. Jancsó e Iris Kantor, contêm exemplos significativos de temas religiosos e sociais que podem ser desenvolvidos a partir desses materiais ${ }^{76}$. A edição crítica de 1676 da biografia panegírica e da descrição do funeral do Visconde de Barbacena oferece um exemplo do tipo de textos que podem ser usados para esta finalidade, mas o estudo das procissões de Corpus Christi por B. Cruz Santos é o mais completo estudo destas atividades no Brasil colonial até agora ${ }^{77}$.

Uma das áreas da História das Religiões no Brasil que cresceu bastante, nas últimas décadas, trata da Inquisição. Esse tipo de pesquisa se apoiou numa sólida compreensão quantitativa das intervenções da Inquisição em Portugal e numa melhor compreensão das suas operações em relação

2000; MELLO E SOUZA, Marina de. Reis negros no Brasil escravista. Belo Horizonte, 2002; REIS, João José. Slave Rebellion in Brazil. Baltimore, 1993. Ver, também: SWEET, James. Recreating Africa. Chapel Hill, 2003. Existem excelentes artigos sobre as influências culturais da África Central no Brasil, no livro de Linda M. Heywood, Central African Cultural Transformations in the American Diaspora. Cambridge, 2002. Ver, por exemplo, KARASCH, Mary. "Central Africans in Central Brazil”, p. 117-152; KIDDY, Elizabeth W. "Who is the king of the Congo? A New Look at African and Afro-Brazilian Kings in Brazil", p. 153-182; SLENES, Robert. "The Great Porpoise-Skull Strike: Central African Water Spirits and Slave Identity in Early Nineteenth-Century Rio de Janeiro", p. 183-210.

75 Ver a discussão em MUKERJ, Chandra; SCHUDSON, Michael. "Popular Culture". In: Annual Reviews in Sociology, v. 12, 1986, p. 47-66.

76 JANCSÓ, István (Org.). Festa. Cultura e sociabilidade na América portuguesa, 2 v. São Paulo, 2001. Cf. PAIVA, José Pedro. Religious ceremonials and images: Power and social meaning. Coimbra, 2002. A análise mais completa do papel desenvolvido pelos festivais religiosos na cultura popular pode ser encontrada em ABREU, Marta. O império do divino. Rio de Janeiro, 1999, que trata do século XIX.

77 SCHWARTZ, Stuart B.; PECORA, Alcir (Eds.). As excelências do governador. São Paulo: Companhia das Letras, 2002; SANTOS, Beatriz Catão Cruz. O corpo de Deus na América. São Paulo: Annablume, 2005. 
aos tribunais civis ou ao processo judicial em outros países ${ }^{78}$. A avaliação do rigor da Inquisição é sempre dependente dos números e dos grupos que são colocados no denominador das operações do tribunal. No entanto, o novo interesse pela Inquisição, enquanto instituição, e o seu estudo pelos historiadores, são utilizados como um importante recurso de documentos que produziu resultados positivos. Um trabalho, como a comparação feita por F. Bethancourt entre a Inquisição espanhola, portuguesa e italiana nos proporcionam comparações mais sólidas entre as diferentes nações ${ }^{79}$. No Brasil, as pesquisas que tratam da Inquisição já tomaram novos rumos. O trabalho fundamental, embora mais antigo, de Sonia Siqueira e Anita Novinsky, e a publicação do relato de várias visitas da Inquisição ao Brasil já tinham criado uma excelente base para a compreensão da instituição e dos seus efeitos. Mais recentemente, Anita Novinsky e suas alunas, como Maria Tucci Carnero e Lina Gorenstein Ferreira da Silva, mostraram que as operações do Santo Ofício continuaram principalmente contra Cristãos novos, até mesmo no século XVIII, em particular em Minas Gerais e Rio de Janeiro. Elas alegam que essas operações tiveram importantes efeitos sociais e econômicos ${ }^{80}$. Mas, também, temos de reconhecer que o principal interesse da Inquisição Portuguesa pelos "Cristãos Novos", e a pergunta: "eles eram judeus ou não eram judeus?", teve um impacto curioso sobre os pesquisadores brasileiros. Outros estudos mostram que o Santo Oficio se

78 Ver, por exemplo, VILLANUEVA, Joaquín Pérez; BONET, Bartolomé Escandell. Historia de la Inquisición en España y América. 3 v. Madrid, 2000; KAMEN, Henry. The Spanish Inquisition. An Historical Revision. New Haven, 1997.

79 BETHENCOURT, Francisco. História das Inquisições. Portugal, Espanha e Itália. Lisboa, 1994. Recentes pesquisas sobre Portugal, como o estudo de J. Coelho sobre a Inquisição de Évora ou o trabalho de M. Tailland sobre esse tribunal de1660 até 1821, o livro de E. Mea sobre a Inquisição de Coimbra, a pesquisa de José Pedro Paiva sobre a bruxaria portuguesa e a sua perseguição em Coimbra, ou a análise primorosa de grupos especiais (estrangeiros, mouriscos e renegados) ou de infrações particulares (bigamia, sodomia) ajudam a encaixar os dados do Brasil num contexto mais amplo. Ver: COELHO, António Borges. Inquisição de Évora. 2 v. Lisboa, 1987; TAILLAND, Michèle Janin-Thivos. Inquisition et société au Portugal. Le cas du tribunal de Évora. Paris, 2002; MEA, Elvira Cunha de Azevedo. A Inquisição de Coimbra no século XVI. Oporto, 1997. Infelizmente, o Tribunal de Lisboa onde todos os casos das colônias do além-mar foram julgados, ainda não foi estudado como mereceria.

80 NOVINSKY, Anita. Cristãos novos na Bahia. São Paulo: Editora Perspectiva, 1972; SIQUEIRA, Sonia. A inquisição portuguesa e a sociedade colonial. São Paulo: Editora Ática, 1978; NOVINSKY, Anita. Inquisição. Prisioneiros do Brasil. Rio de Janeiro, 2002; CARNEIRO, Maria Luiza Tucci. Preconceito racial no Brasil-colônia. São Paulo: Brasiliense, 1983; SILVA, Lina Gorenstein Ferreira da. Heréticos e impuros. Rio de Janeiro, 1995. 
manteve ativo no Nordeste do Brasil, como provam os trabalhos de Bruno Feitler sobre a Paraíba e de Luiz Mott sobre o Maranhão e o Sergipe ${ }^{81}$. O modo de operação do Santo Oficio, no século XVIII, e a ascendência social dos seus assistentes laicos em Pernambuco, são os temas de estudos quantitativos realizados por J. Wadsworth e por Daniela Calainho ${ }^{82}$. A maneira pela qual o tribunal tentou suprimir a dissidência política e religiosa no final da era colonial é o objeto de uma série de estudos elaborados pelo historiador canadense David Higgs ${ }^{83}$.

Em paralelo a essa linha de investigação que analisa as dimensões políticas e sociais da Inquisição, a exploração dos registros da Inquisição desvenda as práticas populares, a religiosidade e todo um conjunto de ideias heterodoxas e heréticas. Dois acadêmicos, Gerardo Pieroni e Timothy Coates, separados ou juntos, estão pesquisando o tema do exílio penal, o degredo, negligenciado há muito tempo. Paraor isso, eles utilizam ambos os registros dos tribunais civis e eclesiásticos ${ }^{84}$. A consulta dos registros da Inquisição nos informa sobre a ortodoxia e a heterodoxia na colônia, onde a liberdade e a exploração sexual eram dependentes do poder e das disparidades de status, de acordo com sexo, cor ou etnia, ou eram baseadas no estado civil dos escravos e das pessoas livres. Esses registros permitem uma plena compreensão da discrepância entre teologia e prática ${ }^{85}$. Meu recente estudo, sobre as atitudes do relativismo ou tolerância religiosa

81 FEITLER, Bruno. Inquisition, juifs et nouveaux-chétiens au Brésil. Louvain, 2003. O historiador francês Nathan Wachtel que produziu La foi du souvenir (Paris, 2002) sobre os Cristãos novos portugueses na América hispânica conduz pesquisas sobre os Cristãos novos da Paraíba também. Ver: MOTT, Luiz. A Inquisição em Sergipe. Aracaju: Fundação Estadual de Cultura, 1989; A Inquisição no Maranhão. São Luis: EDUFMA, 1995.

82 WADSWORDH, James E. Agents of Orthodoxy. Lanham, MD: Roman and Littlefield, 2007; "In the Name of the Inquisition: The Portuguese Inquisition and Delegated Authority in Colonial Pernambuco". In: The Americas, v. 61, n. 1, 2004, p. 19-52. Ver também, do mesmo autor, "Joaquim Marques de Araújo: o poder da Inquisição em Pernambuco no fim do período colonial". In: NIZZA DA SILVA, Maria Beatriz (Org.). De Cabral a Pedro I: Aspectos da colonização portuguesa no Brasil. Oporto, 2001, p. 309-28. Sobre os representativos laicos da Inquisição em geral, ver BUENO, Daniela. Agentes da fé. Familiares da Inquisição portuguesa no Brasil colonial. Bauru: EDUSC, 2006.

83 Ver, por exemplo, HIGGS, David. "O Santo Ofício da Inquisição de Lisboa e a 'Luceferina Assembléia' do Rio de Janeiro na década de 1790". In: Revista do Instituto Histórico e Geográfico Brasileiro, v. 412, n. 2001, p. 239-384.

84 COATES, Timothy. Convicts and Orphans. Forced and State-Sponsored Colonizers in the Portuguese Empire. Stanford: Stanford University Press, 2001; PIERONI, Gerardo. Os excluidos do Reino: A Inquisição portuguesa e o degredo para o Brasil colônia. Brasília: Universidade de Brasília, 2000.

85 VAINFAS, Ronaldo. Trópico dos pecados. Rio de Janeiro, 1997; GOLDSCHMIDT, Eliana Maria Rea. Convivendo com o pecado na sociedade colonial paulista. São Paulo, 1998; MOTT, Luiz. Escravidão, homossexualidade e demonologia. São Paulo, 1988. 
no mundo luso-hispânico Atlântico, definido pela Inquisição como herético, pertence a essa categoria ${ }^{86}$.

Os registros da Inquisição revelam situações individuais e detalhes pessoais; portanto, casos individuais notáveis que serviram de base para um número crescente de estudos biográficos. Embora estudos de casos brasileiros não alcançassem a fama ou sutileza metodológica de "O queijo e os vermes", de Ginzburg, eles oferecem fascinantes perspectivas sobre os contextos mental, social, e político dos protagonistas. Por exemplo, dois estudos sobre Pedro Rates Henequim, um residente de longa data de Minas Gerais, executado pela Inquisição em 1744; o de Freire Gomes, que enfatiza a hibridez religiosa herética de Henequim, e o de Adriana Romeiro que se focaliza sobre suas ideias milenaristas e seus complôs políticos ${ }^{87}$. Podemos acrescentar a primorosa biografia de Luiz Mott sobre uma profetisa de rua, ex-escrava no século XVIII, no Rio de Janeiro. Esse mesmo autor já explorou as numerosas variedades de dissidência e desvio popular em relação às normas da Igreja em outros trabalhos ${ }^{88}$.

O crescimento do interesse pelas formas de expressão Barroca, não só os espetáculos, festas e procissões, mas também as artes e a literatura, e pelas várias dimensões do catolicismo da ContraReforma, enriqueceu o campo e acrescentou novas dimensões à História Social e Cultural. Diogo Ramada Curto forneceu um amplo panorama da produção intelectual numa escala imperial ${ }^{89}$. O grande missionário, pregador, diplomata e escritor Padre Antônio Vieira é o centro de uma nova historiografia cultural, literária e textual que analisa e comenta suas posições proféticas, políticas e teológicas, bem como a sua atividade missionária ${ }^{90}$. Os trabalhos de Vieira Nascimento, Van den Besselaar, Mu-

86 SCHWARTZ, Stuart B. Everyone in their own Law: Salvation and the Origins of Tolerance in the Iberian Atlantic World (no prelo).

87 GOMES, Plínio Freire. Um herege vai ao paraíso. São Paulo, 1997; ROMEIRO, Adriana Romeiro. Um visionário na corte de D. João V. Belo Horizonte, 2001.

88 MOTT Luiz. Rosa Egipcíaca. Uma santa africana no Brasil. Rio de Janeiro, 1993. Ver, por exemplo, MOTT, Luiz. Escravidão, homossexualidade, e demonologia. São Paulo, 1988.

89 CURTO, Diogo Ramada. "A literatura e o império”. In: BETHENCOURT, F.; CHAUDURI, K. (Eds.). História da expansão portuguesa. 5 v. Lisboa, 1998-2000, I, p. 413-433; "As practicas de escrita", III, p. 421-462.

90 O Terceiro Centenário da morte de Padre Vieira em 1997 estimulou um interesse renovado por seu trabalho. Ver, por exemplo, a excelente coletânea no número de Oceanos (v. 30/31, 1997) dedicado a Vieira. Entre as novas contribuições sobre o Padre Vieira, podemos citar: BESSELAAR, José van den. 
hama, Cohen, Silvério Lima e Pécora, bem como os ensaios polêmicos de Alfredo Bosi sobre Vieira e o jesuíta italiano, Antonil, reorientaram o interesse pela interação da literatura e da história. A união benéfica entre a análise literária e a história está exemplificada nos trabalhos de João Adolfo Hansen, em particular no seu estudo sobre Gregório de Matos, o poeta satírico e crítico social baiano do século XVII, e nas pesquisas de Alcir Pécora sobre Vieira e a cultura Barroca ${ }^{91}$. Essas obras fazem parte da história intelectual do Brasil, uma área que é reanimada e revigorada pela guinada cultural. A obra de Iris Kantor Esquecidos e renascidos, sobre as efêmeras sociedades literárias baianas do século XVIII, revelou uma elite colonial buscando no estudo da História seu próprio lugar na vida social e intelectual da colônia ${ }^{92}$. O suntuoso volume de Lilia Moritz Schwarcz sobre a transferência da Corte Portuguesa e da Biblioteca Real de Lisboa para o Rio de Janeiro fornece uma História Cultural da vida social e intelectual quando elites locais e cortesãos portugueses foram obrigados a se juntar, devido às vicissitudes das revoluções atlânticas ${ }^{93}$.

\section{Governar as Colônias}

Em razão da guinada em direção à História Cultural, poucas pessoas teriam predito, há duas décadas, que a história administrativa

António Vieira. Profecia e polêmica. Rio de Janeiro, 2002, e sua edição critica do Livro anteprimeiro da História do futuro. Lisboa, 1985; COHEN, Thomas. The Fire of Tongues. António Vieira and the Missionary Church in Brazil and Portugal. Stanford, 1998; MENDES, Margarida Vieira. A oratória barroca de Vieira. Lisboa, 1989; BORGES, Paulo Alexandre Esteves. A plenificação da história em Padre António Vieira. Lisboa, 1995; LIMA, Luís Filipe Silvério. Padre Vieira: Sonhos Proféticos, profecias oníricas. O tempo do Quinto Império nos sermões de Xavier Dormindo. São Paulo: Humanitas, 2004; PÉCORA, Alcir. Teatro do sacramento. A unidade teológico-retórico-politica dos sermões de Antonio Vieira. São Paulo, 1994. Pécora publicou também uma edição crítica dos sermões em Sermões: Padre Antônio Vieira. 2 v. São Paulo, 20002001. BOSI, Alfredo. Dialética da colonização. São Paulo, 1992.

91 HANSEN, João Adolfo. A sátira e o engenho. Gregório de Matos e a Bahia do século XVII. 2. ed. Campinas: Ateliê Editorial, 2004; PÉCORA, Alcir. Máquina dos gêneros. São Paulo: EDUSP, 2001.

92 KANTOR, Iris. Esquecidos e renascidos. Historiografia acadêmica luso-americana 172459. São Paulo: HUCITEC e Centro de Estudos Bahianos, 2004.

93 SCHWARCZ, Lilia Moritz. A longa viagem da biblioteca dos reis. São Paulo: Companhia das Letras, 2002. 
se tornaria um foco de novas interpretações e controvérsias, mas o papel dominante do Estado na História brasileira talvez tivesse garantido seu principal papel também na historiografia moderna. No Brasil, como em outros países, os últimos vinte anos testemunham o questionamento de uma narrativa, que faz com que o Estado seja o protagonista invariável da História, especialmente nas obras que tratam do período da independência. Mas, em geral, pesquisadores envolvidos com o Brasil não tiveram de colocar o "Estado de volta", uma vez que as abordagens da História Social nunca o tiraram da reflexão. Desde que Raimundo Faoro publicou Os donos do poder (1958), o debate se desenvolveu em torno da sua interpretação do Estado e de sua burocracia, em oposição à sociedade, e também em torno de várias interpretações alternativas em que o Estado é visto como representante ou cativo de grupos específicos de interesse na sociedade. Nos anos 1970, foram publicados estudos clássicos angloamericanos, como os de Alden, Boxer, Maxwell, Russell-Wood e Schwartz que procuraram analisar a maneira como poderes locais e regionais tentaram subverter ou controlar o poder estatal, ou como instituições, tais como as irmandades beneficentes, são capazes de refletir a luta entre poder público e privado. Apesar do fato de que a década de 1980 viu um movimento em direção à privatização e uma retirada do Estado de certos aspectos do planejamento econômico e social no Brasil contemporâneo, a preocupação com o Estado e seu cruzamento com a sociedade está no centro das discussões recentes entre os historiadores do Brasil colonial. O conceito predominante que se destaca no Brasil é o "antigo regime colonial" desenvolvido por Fernando Novais num ensaio, frequentemente reimpresso, e na sua monografia sobre o desenvolvimento do pensamento imperial no Portugal do século XVIII ${ }^{94}$. A partir das interpretações marxistas anteriores de Caio Prado Jr., a análise de Novais ressaltou a natureza mercantilista das relações coloniais, sua dependência no trabalho forçado e as inerentes desvantagens econômicas e, portanto, sociais para o Brasil. Essa análise argumentava que há uma relação, inerentemente, conflituosa entre a colônia e a metrópole, mas, ao

94 Ver "O Brasil nos quadros do Antigo Sistema Colonial" que foi publicado, originalmente, em 1968. Foi recentemente republicado junto com os artigos mais importantes de Novais em NOVAIS, Fernando A. Aproximações. Estudos de história e historiografia. São Paulo: Cosac e Naify, 2006, p. 45-60. Ver, também, NOVAIS, Fernando A. Portugal e Brasil na crise do antigo sistema colonial, 1777-1808. 4. ed. São Paulo: HUCITEC, 1986. 
mesmo tempo, reconhecia as mudanças nessa interdependência e alegava que o sistema mercantilista português continha inerentes contradições, criando, assim, uma crise econômica que resultou na independência do Brasil. Sua tese foi corroborada, de maneira mais formal e quantitativa, por uma série de estudos realizados por José Jobson de Andrade Arruda e por outros pesquisadores que adotaram o paradigma preconizado por Novais e o reforçaram com uma base de dados sólida ou por uma análise econômica mais formal ${ }^{95}$.

Entretanto, nas últimas duas décadas, esse paradigma é cada vez mais examinado a partir de várias perspectivas. Primeiro, uma série de estudos econômicos elaborados por historiadores portugueses, como Valentim Alexandre e Jorge Pedreira, levantou sérios questionamentos sobre as "anomalias estruturais inerentes" do sistema colonial português e argumentou que qualquer crise econômica que caracterizasse a relação entre metrópole e colônia no início do século XIX era o resultado dos acontecimentos políticos de 1807-08 e de seus efeitos econômicos, e não de uma ruptura sistêmica do colonialismo ${ }^{96}$. Novais, Arruda e outros não têm se mostrado dispostos a abrir mão das suas análises, e ambos os lados procuraram reforçar as suas interpretações, integrando novos estudos, como o importante trabalho de Ernst Pijning sobre contrabando ${ }^{97}$. Outra linha de reinterpretação veio de João Fragoso e de alguns de seus colegas no Rio de Janeiro. Em uma série de estudos inovadores e desafiadores, esse autor

95 ARRUDA, José Jobson de Andrade. O Brasil no comércio colonial. São Paulo: Editora Ática, 1980; "Colonies As Mercantile Investments". In: The Political Economy of Merchant Empires. James Tracy (Ed.). Cambridge: Cambridge University Press, 1991.

96 ALEXANDRE, Valentim. Os sentidos do império: Questão nacional e questão colonial na crise do antigo regime português. Porto: Ed. Afrontamento, 1993; PEDREIRA, Jorge M. Estrutura industrial e mercado colonial: Portugal e Brasil. Lisboa: Difel, 1994.

97 PIJNING, Ernst. Controlling Contraband: Mentality, Economy, and Society in EighteenthCentury Rio de Janeiro. Thesis (Ph.d.) - Johns Hopkins University, 1997. Houve uma troca direta entre Jobson Arruda e Pedreira. Ver: PEDREIRA, Jorge M. "From Growth to Collapse: Portugal, Brazil, and the Breakdown of the Old Colonial System (1760-1830)". In: HAHR, v. 80, n. 4, 2000, p. 839-864; ARRUDA, José Jobson de Andrade. "Decadence or Crisis in the Luso-Brazilian Empire: A New Model of Colonization in the Eighteenth Century". In: $H A H R$, v. 80, n. 4, 2000, p. 865-878, seguido por uma discussão entre Pijning e Pedreira in $H A H R$, v. 81, n. 3-4, 2001, p. 733-744. Ver o resumo da avaliação do debate em NEVES, Guilherme Pereira das. "Del imperio Luso-Brasileiro al imperio del Brasil (17891822)". In: ANNINO, A.; CASTRO LEIVA, L.; GUERRA, F.X. (Eds.) De los imperios a las naciones: Iberoamérica. Zaragoza: Ibercaja-Obra Cultural, 1994, p. 169-193. Mais contribuições ao debate podem ser encontradas em CARDOSO, José Luís. A economia política e os dilemas do imperio luso-brasileiro (1790-1822). Lisboa: CNCDP, 2001. 
enfatizou o crescimento autônomo de acumulação de capital e de poder político dentro da colônia, principalmente entre os comerciantes do Rio de Janeiro, e salientou o crescimento da produção e do comércio local, em vez de privilegiar o comércio internacional como a força motriz atrás desse crescimento. Essa interpretação pode ser comparada ao trabalho de outros pesquisadores sobre a economia interna e a importância da agricultura "camponesa" no Brasil, embora ela se esforce a romper com a sombra duradoura da escravidão sobre a natureza da História Colonial. O problema de interpretação para Fragoso e para Fragoso e Florentino é que o comércio de escravos, a escravidão, os latifúndios, a economia e as exportações foram tão entrelaçados com a pequena agricultura e o abastecimento de cidades e plantações que parece difícil operar uma separação analítica entre os dois aspectos da economia.

Fragoso e seus colegas também enfatizaram a origem, a persistência e a importância dos grupos coloniais nas instituições de governo. De certa maneira, suas interpretações foram possíveis graças à chegada de uma nova geração de historiadores em Portugal pós-Salazar, cuja reinterpretação dos primeiros tempos do Portugal Moderno tem implicações diretas para o estudo do Brasil. O historiador português do Direito António Manuel Hespanha e um grupo de pesquisadores associados à Universidade Nova de Lisboa reexaminaram instituições, estruturas e grupos sociais do Portugal Moderno dos primeiros tempos. O estudo principal de Hespanha, Às vésperas do Leviathan, embora nunca abordasse as colônias do além-mar, sugeriu que a potência real e os recursos estatais permaneceram limitados até mesmo no século XVII. Hespanha também escreveu um estudo sugestivo, utilizando o conceito do "dom" de Marcel Mauss para explicar a natureza essencialmente patrimonial da dispensa real de ofício e de honra para explicar os métodos de governo nos primeiros tempos do Portugal Moderno ${ }^{98}$. Essas ideias estimularam acadêmicos brasileiros, que queriam enfatizar a situação paralela na colônia, onde elites locais continuaram a exercer um controle social e econômico e onde uma utilização manipulativa de uma economia de recompensas possibilitou a integração das elites locais no sistema imperial. Esses acadêmicos julgaram que um ensaio do historiador Joaquim Romero

98 HESPANHA, António Manuel. Às vésperas do Leviatán. Instituições e poder politico. 2. ed. Coimbra: Livraria Almedina, 1994; La gracia del derecho. Madrid: Centro de Estudios Constitucionales, 1994. 
Magalhães de Coimbra era, particularmente, importante. Nesse trabalho, ele afirma que a adesão aos conselhos e senados das câmaras portuguesas criou um tipo de nobreza provincial, com importantes consequências sociais e políticas ${ }^{99}$. Baseando-se nesses modelos interpretativos e nos trabalhos que destacam a relação dinâmica entre o centro imperial e suas periferias, um grupo de pesquisadores, cujo objeto de estudo principal é o Rio de Janeiro (e lá vivem), desafiou o paradigma de Novais. Eles sugerem que a melhor maneira de compreender o Brasil está resumida na expressão "o ancién regime nos trópicos". Enfatizam as adaptações e a cooperação de certos grupos com a ajuda do aparelho de governo imperial na colônia e, portanto, rompem com um modelo estrutural e competitivo "dualista" de colônia versus império. Entre os principais autores desta nova escola, João Fragoso destacou a manipulação dos cargos burocráticos como um trampolim para o poder pessoal e o status de elite entre os primeiros colonizadores do Rio de Janeiro e, mais tarde, ele enfatizou o desenvolvimento de uma classe mercantil local, no século XVIII, cujo controle de uma economia local, cada vez mais importante, forneceu a base da sua riqueza e da sua autoridade. No entanto, ele argumentou que o investimento contínuo dessas elites em terras e escravos - menos lucrativo do que o comércio aponta - mostra que o pensamento dessas elites era ainda pré-capitalista ${ }^{100}$. Fernanda Bicalho analisou o crescimento do poder local, expresso através da câmara do Rio de Janeiro, durante todo o século XVIII, enquanto Maria de Fátima Gouvêa estudou a circulação dos oficiais dentro do império e as mudanças administrativas usadas para integrar o Brasil no sistema imperial ${ }^{101}$. O objeto desses estudos focaliza os poderes locais com

99 MAGALHÃES, Joaquim Romero. "As estruturas sociais de enquadramento da economia portuguesa de Antigo regime: os conselhos". In: Notas Econômicas, v. 4, 1994, p. 23-34. O trabalho de A.J.R. Russell-Wood influenciou essa nova orientação. Ver, em particular, "Centro e periferia no nundo luso-brasileiro". In: Revista Brasileira de História, v. 18, n. 36, 1998, p. 187-250.

100 Resumi o argumento de Fragoso de maneira mais ampla em "Somebodies and Nobodies in the Body Politic: Mentalities and Social Structures in Colonial Brazil". In: Latin American Research Review, v. 31, n.1, 1996, p. 113-34.

101 FRAGOSO, João. “A nobreza da república: Notas sobre a formação da primeira elite senhorial do Rio de Janeiro (séculos XVI e XVII)”. In: Topoi. Revista de História, v. I, 2000, p. 45-122; Homens da grossa aventura: Acumulação e hierarquia na praça mercantile do Rio de Janeiro, 1790-1830, 2. ed. Rio de Janeiro: Civilização Brasileira, 1998; BICALHO, Maria Fernanda. A cidade e o império. $O$ Rio de Janeiro no século XVIII. Rio de Janeiro: Civilização Brasileira, 2003; GOUVÊA, Maria de Fátima. "Redes de poder na América portuguesa: O caso dos homens bons do Rio de Janeiro, 1790-1822". In: Revista Brasileira de História, v. 18, n. 36, 1998, p. 297-330; "Poder, justiça e soberania no Império colonial português, século XVIII". In: Leituras. Revista da Biblioteca Nacional. Lisbon, v. 6, 2000. A posição da escola carioca e exemplos dos melhores trabalhos estão em FRAGOSO, João; BICALHO, M. Fernanda; 
pretensões aristocráticas, que atuam como uma nobreza colonial, mas ainda resta saber se o simples fato de se autoproclamarem nobres os transformou em fidalgos. De todo modo, temos sorte, agora, em possuir uma melhor base para avaliar tais alegações, pois a nossa compreensão do papel da nobreza na sociedade portuguesa e brasileira foi transformada por trabalhos, tais como o estudo da casa de Bragança por Mafalda Soares da Cunha e, em particular, os trabalhos de Nuno Freitas Monteiro. Sua análise monumental, cuidadosamente elaborada, das grandes casas nobres do Portugal do Século XVIII, das suas estratégias e possessões, mostrou a razão dessa classe social ter permanecido politicamente poderosa por tanto tempo. Seu trabalho sugere, de várias maneiras, a importância da presença ou da ausência de uma nobreza no contexto colonial. Esse assunto é, de fato, objeto do livro de Nizza da Silva sobre a aristocracia brasileira, um setor que sempre buscou gozar de um status nobre ${ }^{102}$. A tentativa de ver a nobreza como uma das elites potenciais, metropolitanas ou colônias - seja ela, social, burocrática, econômica - está por trás de vários estudos que entram na composição do projeto Optima pars. Esse conceito está no centro de uma tendência na historiografia recente sobre a organização social e política do Império Português e de seus componentes ${ }^{103}$. Os estudos de Monteiro Gonçalves sobre a nobreza, de Subtil sobre o Desembargo do Paço e a burocracia jurídica, de Cardim sobre as Cortes e o Tribunal, de Freire Costa sobre as frotas da Companhia do Brasil e de Fernanda Olival sobre as ordens militares, abriram novas perspectivas em relação ao funcionamento da colônia brasileira dentro dos parâmetros e modelos da metrópole. No entanto, as suas primeiras obras tratavam do Portugal e não das colônias ${ }^{104}$. Isso também já está mudando. Um grande

GOUVÊA, Maria de Fátima (Eds.). O antigo regime nos trópicos: A dinâmica imperial portuguesa (séculos XVI-XVIII). Rio de Janeiro: Civilização Brasileira, 2001. Ver, também, FRAGOSO, João; GOUVÊA, Maria de Fátima; BICALHO, Maria Fernanda Baptista. "Uma leitura do Brasil colonial: bases de materialidade e da governabilidade no Império". In: Penelope, v. 23, 2000, p. 67-88.

102 CUNHA, Mafalda Soares da. A Casa da Bragança, 1560-1640. Lisboa: Editora Estampa, 2000; MONTEIRO, Nuno Gonçalo Freitas. O crepúsculo dos grandes (1750-1832). Lisboa: Imprensa Nacional, 1996; Elites e poder: entre o antigo regime e o liberalismo. Lisboa: Imprensa de Ciências Sociais, 2003; NIZZA DA SILVA, Maria Beatriz. Ser Nobre na Colônia. São Paulo: Editora UNESP, 2005.

103 MONTEIRO, Nuno G. F.; CARDIM, Pedro; CUNHA, Mafalda Soares da (Eds.). Optima pars. Elites Ibero-Americanas do Antigo Regime. Lisboa: Imprensa de Ciências Sociais, 2005.

104 SUBTIL, José M. O Desembargo do Paço (1750-1833). Lisboa: Universidade Autónoma de Lisboa, 1996; CARDIM, Pedro. Cortes e cultura politica no Portugal do Antigo Regime. Lisboa: Edições Cosmos, 1998; OLIVAL, Fernanda. As ordens militares e o estado moderno. Honra, mercê, e venalidade em Portugal (1641-1789). Lisboa: Estar, 2001. 
número de pesquisas sobre as elites está sendo realizado no mundo iberoamericano, incluindo, atualmente, pesquisadores brasileiros, portugueses e espanhóis. Esse projeto já produziu um excelente estudo proposográfico de todos os governadores e capitães-mor do Império Português Atlântico nos séculos XVII e XVIII ${ }^{105}$. Mas, de forma semelhante, o mundo acadêmico brasileiro está reembolsando sua dívida para Portugal, publicando notáveis livros de História Social e Cultural, produzidos por historiadores brasileiros sobre Portugal Moderno dos primeiros tempos ${ }^{106}$.

As divergências de interpretação que, na realidade, giram em torno da ênfase dada às relações conflituosas entre colônia e metrópole ou ao relacionamento colaborativo entre elites locais e governo imperial, geraram um interesse renovado pela natureza do governo e da administração. Numerosos atos de colóquios foram publicados sobre esses temas e várias revistas acadêmicas de História dedicaram números especiais à administração colonial ${ }^{107}$. Laura de Mello e Souza escreveu, talvez, a mais séria crítica dos novos "Tropicalistas", destacando a profunda influência da escravidão no Brasil. De fato, ela alega que a escravidão moldou a organização social e o sistema de governo do país, diferentemente de qualquer outro "ancién régime" europeu. Mello e Souza investigou, em seus ensaios, alguns indivíduos cujas carreiras iluminam o estilo e o conteúdo da administração no século XVIII ${ }^{108}$. O debate, porém, certamente, não

105 CUNHA, Mafalda Soares da; MONTEIRO, Nuno Gonçalo F. "Governadores e capitãesmores do império Atlântico português nos séculos XVII e XVIII" (artigo não publicado).

106 A esse respeito, podemos citar: HERMANN, Jacqueline. No reino do desejado. A construção do sebastianismo em Portugal séculos XVI e XVII. São Paulo: Companhia das Letras, 1998; MEGIANI, Ana Paula Torres. O rei ausente. Festa e cultura política nas visitas dos Felipes a Portugal (1581-1619). São Paulo: Alameda, 2004; MONTEIRO, Rodrigo Bentes. O rei no expelo - a monarquia portuguesa e a colonização da Amão da América. São Paulo: Hucitec, 2002; DEL PRIORE, Mary. O mal sobre a terra. Uma história do terremoto de Lisboa. Rio de Janeiro: Topbooks, 2003; SANTOS, Georgina Silva dos. Oficio e sangue. A irmandade de São Jorge e a Inquisição de Lisboa. Lisboa: Edições Colibri, 2005. Um predecessor digno de destaque é FRANÇA, Eduardo D'Oliveira. Portugal na época da Restauração. São Paulo: HUCITEC, 1997, que foi anteriormente divulgado como um "clássico" underground desde que tinha sido completado como tese de doutorado em 1951.

107 BICALHO, Maria Fernanda; FERLINI, Vera Lúcia Amaral. Modos de governar. São Paulo: Alameda, 2005. Algumas revistas acadêmicas de história que dedicaram um espaço enorme ao tema da administração colonial são: Revista Brasileira de História, v. 18, n. 36, 1998, "Do Império português ao Império do Brasil"; Penelope, Lisboa, v. 27, 2002, "Política e administração no Atlântico"; Tempo, v. 7, n. 13, 2002, "Política e administração no mundo Luso-brasileiro".

108 MELLO E SOUZA, Laura de. O sol e a sombra. Política e administração na América portuguesa no século XVIII. São Paulo: Companhia das Letras, 2006. 
terminou, e estimulou um interesse renovado pelo lugar do Brasil dentro do sistema imperial português.

No entanto, o período que é tratado nas relações entre Brasil e Portugal se situa antes dos meados do século XVIII. O período que vai da queda de Pombal até a independência do Brasil e a formação de um EstadoNação também virou objeto de interesse intenso da parte dos pesquisadores. Os debates enfocam a natureza da crise econômica do regime colonial e se essa "crise" foi estrutural ou dependente da conjuntura política especial das invasões napoleônicas. Esses debates, também, tratam da relação entre o governo imperial e os poderes locais na colônia ${ }^{109}$. Que, por sua vez, levou a um renovado interesse pelos criadores e executores da política imperial no século XVIII. Os estudos de Diniz Silva sobre Dom Luis da Cunha, no início do período; de Maxwell sobre Pombal, nos meados do século; de Mansuy Diniz sobre Dom Rodrigo de Souza Coutinho, e de Trindade Valadares sobre Martinho de Melo e Castro, no final do século, tentaram usar essas vidas e esses pensamentos para compreender a política imperial ${ }^{110}$. Recentes pesquisas acrescentaram outras dimensões a essas questões, como L. Schwarcz e M.B. Nizza da Silva, que estudaram o contexto cultural desse período, ou como J. Pinto Furtado, cujo trabalho se concentra sobre os usos e representações da conspiração de 1788, em Minas Gerais, ou ainda como Kristin Schulz, que escreve sobre os aspectos políticos e culturais da transferência da Corte para Lisboa ${ }^{111}$. István Jancso havia publicado duas excelentes coletâneas que representam o trabalho de um número crescente de estudos imaginativos sobre o período da construção da nação nos anos 1820 e $1830^{112}$. Essas obras não se enquadram nos limites do presente

109 CARDOSO, José Luís. A economia politica e os dilemas do império luso-brasileiro (17901822). Lisboa: CNCDP, 2001.

110 CUNHA, Luís da. Instruções politicas. Abílio Diniz Silva (Ed.). Lisboa: CNCDP, 2001; MAXWELL, Kenneth. Pomba. Paradox of the Enlightenment. Cambridge: Cambridge University Press, 2001; SILVA, Andrée Mansuy-Diniz. Portrait d'un homme d'État: D. Rodrigo de Souza Coutinho, Comte de Lindares, 1755-1812. 2 v. Paris: Centre Cultural Calouste Gulbenkian, 2006; VALADARES, Virginia Maria Trindade. A sombra do poder. Martinho de Melo e Castro e a administraçao de Minas Gerais (17701795). São Paulo: HUCITEC, 2006.

111 SCHWARCZ, Lilia Moritz. A longa viagem; NIZZA DA SILVA, Maria Beatriz. A cultura luso-brasileira. Da reforma da Universidade à independência do Brasil. Lisboa: Editorial Estampa, 1999; SCHULTZ, Kristin. Tropical Versailles. Empire, Monarchy, and the Portuguese Royal Court in Rio de Janeiro. New York: Routledge, 2001.

112 JANCSÓ, István (Ed.). Independência: história e historiografia. São Paulo: HUCITEC, 2005; Brasil: Formação do estado e da nação. São Paulo-Ijuí: HUCITEC, 2003. 
ensaio, mas é justo dizer que demonstraram que a antiga periodização baseada na cronologia política já não é mais útil para os novos estudos culturais e sociais. Com efeito, esses estudos revelaram a continuidade entre uma América portuguesa, baseada na escravidão, que se enxergava como uma colônia de um império, e um Brasil recém-independente, onde os responsáveis consideravam a escravidão e o império como o destino da nação, enquanto que muitos dos seus cidadãos e aqueles que pretendiam se juntar a eles tentavam se livrar da escravidão e do império. 